\title{
PENGARUH MOTIVASI TERHADAP MINAT BELAJAR DARING SISWA SDN PANNARA \\ KOTA MAKASSAR
}

\section{SKRIPSI}

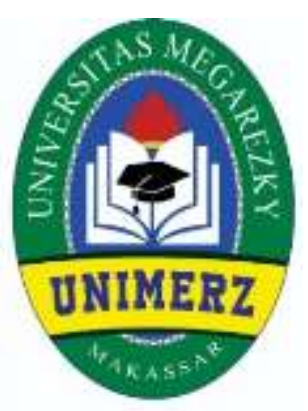

NURUL FADILAH

PROGRAM STUDI PENDIDIKAN GURU SEKOLAH DASAR FAKULTAS KEGURUAN DAN ILMU PENDIDIKAN UNIVERSITAS MEGAREZKY 


\section{PENGARUH MOTIVASI TERHADAP MINAT BELAJAR DARING SISWA SDN PANNARA KOTA MAKASSAR}

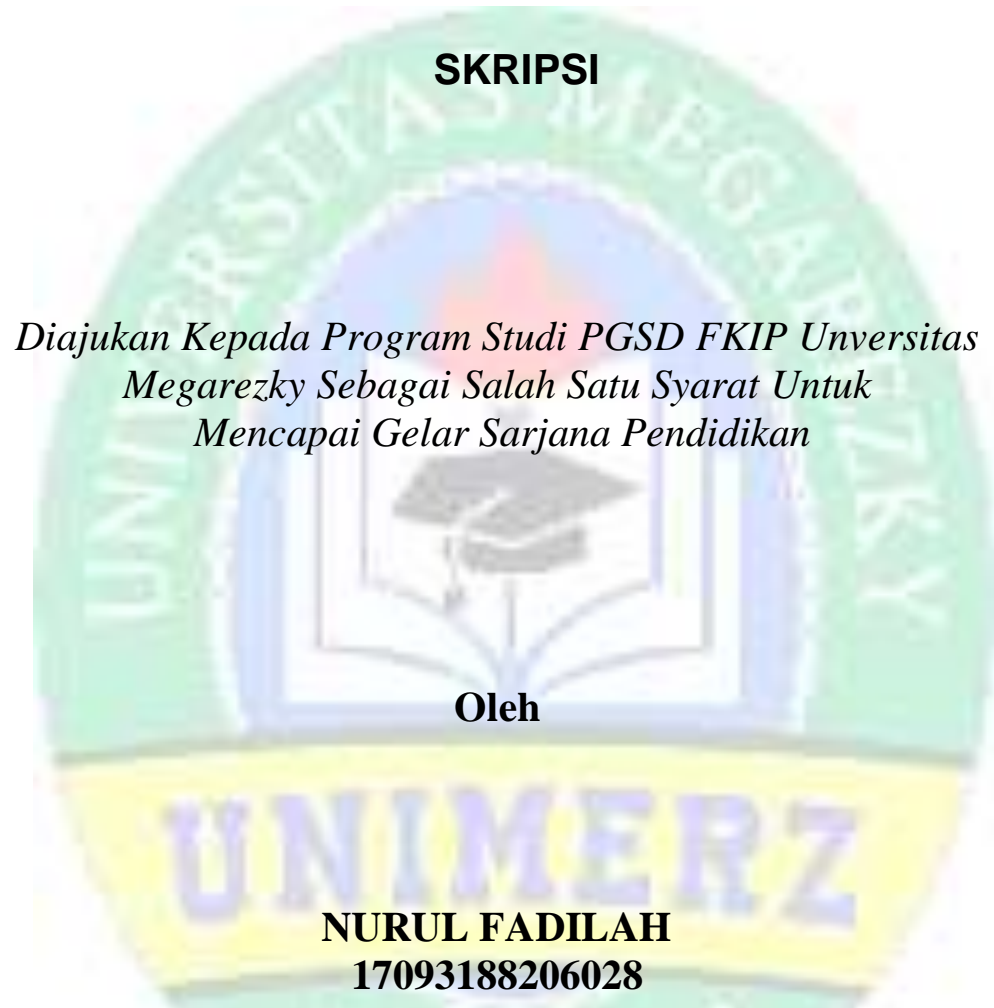

PROGRAM STUDI PENDIDIKAN GURU SEKOLAH DASAR FAKULTAS KEGURUAN DAN ILMU PENDIDIKAN UNIVERSITAS MEGAREZKY 2021 


\section{DAFTAR ISI}

HALAMAN JUDUL

HALAMAN SAMPUL ii

PERSETUJUAN PEMBIMBING iii

HALAMAN PENGESAHAN iv

HALAMAN PENGESAHAN v v

PERNYATAAN KEASLIAN SKRIPSI vi

MOTTO DAN PERSEMBAHAN vii

KATA PENGANTAR viii

DAFTAR ISI

DAFTAR TABEL

DAFTAR BAGAN xiv

DAFTAR LAMPIRAN $\quad$ Xv

$\begin{array}{lll}\text { ABSTRAK } & \text { xvi }\end{array}$

BAB I PENDAHULUAN 1
A. Latar Belakang 1
B. Rumusan Masalah 6
C. Tujuan Penelitian 6
D. Manfaat Penelitian 6

BAB II TINJAUAN PUSTAKA $\quad 8$

A. Tinjauan Pustaka $\quad 8$

1. Motivasi Belajar 8

2. Minat Belajar DARING 15 
B. Penelitian Relevan 24

C. Kerangka Pikir 24

$\begin{array}{ll}\text { D. Hipotesis Penelitian } & 27\end{array}$

BAB III METODE PENELITIAN 28

A. Jenis Dan Desain Penelitian 28

B. Waktu dan Lokasi Penelitian 29

C. Variabel Penelitian dan Definisi Operasional 29

D. Populasi dan Sampel Penelitian 30

E. Instrumen Penelitian 31

F. Teknik Pengumpulan Data 34

G. Teknik Analisis Data 40

BAB VI HASIL PENELITIAN DAN PEMBAHASAN 43

A. Hasil Penelitian 43

B. Pembahasan 53

BAB V PENUTUP

A. Kesimpulan 56

B. Saran 56

$\begin{array}{lr}\text { DAFTAR PUSTAKA } & 58\end{array}$

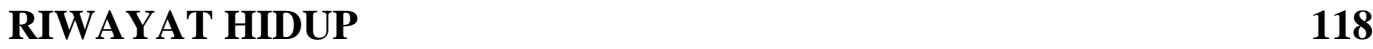




\section{BAB I}

\section{PENDAHULUAN}

\section{A. Latar belakang}

Pendidikan merupakan salah satu kebutuhan yang harus dimiliki setiap manusia agar dapat menjadi generasi muda yang berkualitas. Menurut Ki Hajar Dewantara (Ngalimun, 2017: 13), mengartikan pendidikan sebagai usaha menuntun segenap kekuatan kodrat yang ada pada anak baik individu manusia maupun sebagai anggota masyarakat agar dapat mencapai kesempurnaan hidup. Pendidikan merupakan usaha sadar dan terencana yang bertujuan untuk mengembangkan potensi manusia yang ada, dan membentuk manusia cerdas, berkarakter, serta berkepribadian yang baik, yang diharapkan dapat memajukan dan mengharumkan nama bangsa dan negara dimasa mendatang, febi Laksono dan Arif Widagdo (2018: 64)

Berdasarkan Undang-Undang Republik Indonesia No. 20 Tahun 2003 tentang Sistem Pendidikan Nasional pasal 1, disebutkan bahwa :

"Pendidikan adalah usaha sadar dan terencana untuk mewujudkan suasana belajar dan proses pembelajaran agar peserta didik secara aktif mengembangkan potensi dirinya untuk memiliki kekuatan spiritual, keagamaan, pengendalian diri, kepribadian, kecerdasan, akhlak mulia, serta keterampilan yang di perlukan dirinya, masyarakat, bangsa dan negara".

Sebagaimana yang dijelaskan Undang-Undang No. 20 tahun 2003 (DEPDIKNAS 2003, 7) menyatakan bahwa tujuan Pendidikan Nasional adalah untuk mengembangkan kemampuan dan membentuk watak serta peradaban bangsa yang bermartabat dalam rangka mencerdaskan kehidupan bangsa Perawati 
Bte Abustang, dkk (2018: 77) mengatakan pendidikan yang mampu mendukung pembangunan dimasa mendatang adalah pendidikan yang mampu mengembangkan potensi peserta didik, sehingga mampu menghadapi dan memecahkan problema kehidupan yang di hadapinya. Pentingnya pendidikan bagi suatu negara adalah apabila negara itu maju maka pendidikan warga negaranya juga akan maju dan berkarakter. Undang-Undang RI No. 20 tahun 2003 tentang SISDIKNAS pasal 3 menjelaskan bahwa :

"Pendidikan nasional berfungsi mengembangkan kemampuan dan membentuk watak serta peradaban bangsa yang bermartabat dalam rangka mencerdaskan kehidupan bangsa, bertujuan untuk berkembangnya potensi siswa agar menjadi manusia yang beriman dan bertakwa kepada Tuhan Yang Maha Esa, berakhlak mulia, sehat, berilmu, cakap, kreatif, mandiri, dan menjadi warga negara yang demokratis, serta bertanggung jawab".

Sejalan dengan tujuan pendidikan nasional, maka untuk mewujudkannya di perlukan peran dari berbagai pihak yaitu guru, pemerintah, sarana prasarana, dan orang tua. Salah satu yang sangat penting adalah terkait peran orang tua. Di dalam sebuah keluarga peran orang tua sangat penting, terlebih lagi ketika anak memasuki usia sekolah dan usia menempuh pendidikan, orang tualah yang berperan aktif untuk membentuk watak dan mengembangkan potensi anak.

Pendidikan merupakan suatu jalan untuk mengembangkan dan mengarahkan diri seseorang menjadi manusia yang memiliki kepribadian yang utama dan sempurna. Melalui pendidikan, manusia dapat mengembangkan kepribadian jasmani maupun rohani kearah yang lebih baik. Oleh karena itu, pendidikan memiliki peran yang sangat penting terhadap pertumbuhan dan perkembangan seseorang. Pendidikan adalah investasi jangka panjang yang tidak 
hanya di arahkan dalam mencetak sumber daya manusia yang mampu bekerja melainkan mampu mengoptimalkan kemampuan berfikir dalam menjalankan pekerjaannya guna mencapai fungsi tersebut, maka perlu upaya-upaya meningkatkan kualitas manusia, baik aspek kemampuan, kepribadian maupun tanggung jawab sebagai warga masyarakat, Saipul Jamal (2013: 1).

Pendidikan pada dasarnya merupakan usaha manusia untuk meningkatkan ilmu pengetahuan, baik yang di dapat dari lembaga formal maupun informal. Pendidikan formal adalah jalur pendidikan yang terstruktur dan berjenjang yang terdiri atas pendidikan dasar, pendidikan menengah, dan pendidikan tinggi. Sedangkan pendidikan informal adalah jalur pendidikan keluarga dan lingkungan. untuk mencapai hal tersebut maka diperlukan tujuan pendidikan yang tepat, Fungsi pendidikan adalah sebagai instrument penting yang di perlukan untuk membantu proses menumbuh-kembangkan bakat, potensi dan minat peserta siswa secara efektif yang berguna untuk mencapai tujuan pendidikan yang di harapkan, Ahmadi (2017).

Pendidikan pada hakikatnya adalah usaha sadar untuk mengembangkan seluruh aspek kepribadian dan kemampuan manusia dalam kebersamaannya baik yang berada di lingkungan sekolah maupun di luar sekolah. Masalah pendidikan muncul bersama dengan keberadaan manusia, bahkan pendidik merupakan refleksi dari budayaan manusia. Melalui pendidikan, kebudayaan manusia dari generasi kegenerasi di wariskan. Seiring dengan perkembangan zaman yang makin maju maka manusia di tuntut untuk menguasai ilmu pengetahuan dan 
teknologi. Ilmu pengetahuan hanya bisa di peroleh melalui pendidikan baik pendidikan formal maupun pendidikan informal, Kamal (2013:6)

Tercapainya tujuan pendidikan tidak terlepas dari dukungan lingkungan social yaitu lingkungan keluarga yaitu orang tua yang berperan penting memberikan pembelajaran awal dan utama bagi anaknya. Dari keluarga kita diajari cara, sikap, dan sifat untuk berinteraksi dengan orang lain di dalam maupun di luar keluarga, Perawati Bte Abustang dkk, (2018:78)

Pengaruh motivasi belajar akan menyebabkan terjadinya suatu perubahan energi yang ada pada diri siswa, sehingga akan mempengaruhi gejala kejiwaan, perasaan, dan emosi untuk bertindak atau melakukan sesuatu. Adanya motivasi belajar yang besar dalam diri siswa merupakan syarat agar siswa terdorong oleh kemauannya sendiri untuk berbagai kesulitan belajar yang di hadapi

Peran motivasi dalam proses dalam pembelajaran motivasi siswa dapat dianalogikan sebagai bahan bakar untuk menggerakan mesin motivasi belajar, mendorong siswa perilaku berperilaku aktif untuk berprestasi didalam kelas, tetapi motivasi yang terlalu kuat justru dapat berpengaruh negative terhadap ke efektifan usaha belajar siswa, dikarenakan perlu jangka waktu untuk meresapi, menghayati, dan melakukan bagaimana teori motivasi tersebut bisa diterapkan didalam kehidupan sehari-sehari khususnya dalam pendidikan.

Hamali, S.S., M.M (2018: 133), Motivasi adalah suatu faktor yang mendorong seseorang untuk melakukan sesuatu aktivitas tertentu, oleh karena itu motivasi sering diartikan sebagai faktor pendorong perilaku seseorang. Setiap aktivitas yang dilakukan oleh seseorang pasti memiliki suatu faktor yang 
mendorong aktivitas tersebut. Faktor pendorong dari seseorang untuk melakukan suatu aktifitas tertentu pada umunya serta keinginan orang tersebut. Kebutuhan dan keinginan seseorang berbeda dengan kebutuhan dan keinginan orang lain. Perbedaan kebutuhan dan keinginan seseorang itu terjadi karena proses mental yang terjadi dalam diri orang tersebut. Proses mental itu merupakan pembentukan persepsi pada diri orang yang bersangkutan dan proses pembentukan persepsi diri pada hakikatnya merupakan proses belajar seseorang terhadap segala sesuatu yang dilihat dan dialaminya dari lingkungan yang ada disekitarnya"

Winardi mengemukakan (2016:6), bahwa motivasi merupakan suatu kekuatan potensial yang ada didalam diri seorang manusia,yang dapat dikembangkannya sendiri atau dikembangkan oleh sejumlah kekuatan luar yang pada intinya berkisar sekitar imbalan moneter dan imbalan moneter, yang dapat mempengaruhi hasil kinerjanya secara positif atau negatif.

Motivasi belajar dan minat belajar DARING siswa akan menimbulkan keingintahuan dan kesenangan belajar itu bisa diperoleh dari ilmu pengetahuan yang di ajarkan dan cara guru menyampaikannya. Jika bahan pembelajaran dan cara guru menyampaikan pembelajaran tidak sesuai dengan minat siswa, maka siswa yang bersangkutan tidak akan belajar dengan baik, karena tidak ada daya Tarik baginya.

Berdasarkan hasil penelitian di SDN Pannara Kota Makassar pada 25 Juni 2021 diperoleh informasi bahwa siswa memiliki tingkat motivasi belajar dan minat belajar DARING yang berbeda-beda, hal itu berpengaruh pula pada motivasi belajar dan minat belajar DARING siswa dalam mengikuti kegiatan 
belajar. Cara mengajar guru juga berpengaruh pada ketertarikan siswa dalam mengikuti pembelajaran, motivasi belajar dan minat belajar daring sangat berperan penting dalam proses pembelajaran, dimana pembelajaran dilakukan secara DARING guna meningkatkan minat belajar siswa, dan turut bekerja sama dengan orang tua untuk berperan dalam pembelajaran DARING siswa.

Berdasarkan latar belakang masalah yang ada diatas maka peneliti menyimpulkan bahwa untuk memecahkan masalah peneliti mengangkat judul "Pengaruh Motivasi Terhadap Minat Belajar Daring Siswa SDN Pannara Kota Makassar".

\section{B. Rumusan Masalah}

Berdasarkan uraian latar belakang di atas, maka rumusan masalah dalam penelitian ini adalah apakah ada pengaruh motivasi terhadap minat belajar DARING siswa SDN Pannara Kota Makassar?

\section{Tujuan Penelitian}

Sesuai dengan rumusan masalah yang telah di uraikan di atas, maka tujuan dalam penelitian ini adalah untuk mengetahui pengaruh motivasi terhadap minat belajar DARING siswa SDN Pannara Kota Makassar

\section{Manfaat Penelitian}

Dalam suatu penelitian, diharapkan menghasilkan suatu yang bermanfaat. Adapun manfaat penelitian ini adalah :

1. Manfaat teoritis

a. Sebagai karya ilmiah hasil penelitian yang diharapkan dapat memberikan konstribusi bagai perkembangan ilmu pengetahuan, 
khususnya mengenai pengaruh motivasi terhadap minat belajar DARING siswa SDN Pannara Kota Makassar

b. Hasil penelitian ini dapat digunakan sebagai pedoman untuk kegiatan penelitian selanjutnya.

2. Manfaat praktis

a. Bagi siswa, melalui penelitian ini di harapkan dapat menambah wawasan peserta didik mengenai faktor yang mempengaruhi motivasi belajar sehingga dapat menimbulkan minat belajar DARING yang akan dicapai.

b. Bagi guru, sebagai bahan pertimbangan untuk yang sesuai dengan motivasi belajar dalam rangka meningkatkan minat belajarnya

c. Bagi peneliti, untuk memperoleh pengalaman secara langsung dalam mengetahui motivasi belajar dan minat belajar DARING siswa sehingga dapat disimpulkan pengaruh motivasi belajar dan minat belajar DARING siswa.

d. Bagi pembaca, untuk menambah wawasan terkait pengaruh motivasi terhadap minat belajar DARING siswa. 


\section{BAB II}

\section{TINJAUAN PUSTAKA}

\section{A. Tinjauan Pustaka}

\section{Pengertian Motivasi}

Motivasi berasal dari kata lain motive yang berarti dorongan atau bahasa inggrisnya to move. Motif diartikan sebagai sebagai kekuatan yang terdapat dalam diri organisme yang mendorong untuk berbuat (driving force). Motif tidak berdiri sendiri, tetapi saling berkaitan dengan faktor-faktor lain, baik faktor eksternal, maupun faktor internal. Hal-hal yang mempengaruhi motif disebut dengan motivasi, Motivasi adalah sebuah dorongan, hasrat ataupun minat yang begitu besar dalam diri, untuk mencapai suatu keinginan, cita-cita dan tujuan tertentu. Adanya motivasi akan membuat invidu berusaha sekuat tenaga untuk mncapai yang diinginkannya.

Menurut Ahmad Susanto (2019:165), menyatakan bahwa motivasi dapat di pandang sebagai suatu istilah umum yang menunjukkan kepada pengaturan tingkah laku individu dimana kebutuhan-kebutuhan atau dorongan-dorongan dari dalam dan insentif dari lingkungan mendorong individu untuk memuaskan kebutuhan-kebutuhannya atau berusaha untuk menuju tercapainya tujuan yang di harapkan, motivasi suatu proses di inisiasikannya dan di pertahankannya aktivitas yang di arahkan pada pencapaian tujuan. Dimana motivasi merupakan sebuah proses ketimbang sebuah hasil serta menyangkut berbagai tujuan yang memberikan daya penggerak dan arah bagi tujuan. 
Hasibuan (2016:73), menyebutkan bahwa motivasi merupakan hal yang menyebabkan, menyalurkan dan mendukung perilaku manusia supaya mau bekerja giat dan antusias guna mencapai hasil yang optimal, dan Menurut Mangkunegara (2013:33) adalah suatu kondisi yang menggerakan invidu supaya mampu untuk mencapai tujuan dan motifnya.

Motivasi juga memiliki fungsi dan tujuanya sendiri, maka dibawah ini akan dijelaskan mengenai fungsi dan tujuan motivasi:

a. Menetukan arah langkah

Motivasi akan dapat menuntung langkah dalam hidup. Baik seperti Cita-cita yang akan dicapai, prestasi yang akan didapat, maupun segala hal yang diinginkan.

b. Menentukan keputusan tindakan

Saat menjalani kehidupan, tentu akan banyak tindaka-tindakan yang diambil, baik beresiko kecilhingga besar. Tujuan dan motivasi itu sendiri adalah untuk menetukan setiap tindakan yang diambil.

c. Menyeleksi perbuatan

Melalui motivasi, anda akan dapat menetukan berbagai perbuatan yang perlu dan yang tidak perlu. Artinya, anda akan mampu menentukan perbuatan yang memberikan hasil baik kedepanya andapun akan mampu berbuat dengan resiko paling kecil.

Motivasi belajar merupakan unsur yang sangat penting dalam proses pembelajaran. Karena tanpa disadari bahwa motivasi belajar dapat berpengaruh 
dengan aktif dan pasifnya siswa dalam mengikuti proses pembelajaran didalam kelas.

Wingkel (Aina Muliana, 2018) mengartikan motivasi belajar adalah segala usaha didalam diri sendiri yang menimbulkan kegiatan belajar, dan menjamin kelangsungan dari kegiatan belajar serta memberi arah pada kegiatan-kegiatan belajar sehingga tujuan yang dikehendaki tercapai.

Motivasi belajar merupakan faktor psikis yang bersifat non intelektual dan berperang dalam hal menumbuhkan semangat dalam belajar untuk individu. Iskandar dan Trinora (2015:7) motivasi belajar adalah daya penggerak dari dalam diri invidu untuk melakukan kegiatan belajar untuk menambah pengetauan dan keterampilan serta pengalaman.

Khodijah (2016: 157) motivasi belajar merupakan faktor psikis non intelektual. Perannya yang khas adalah dala penumnuhan gairah perasaan dan semangat untuk belajar. Motivasi belajar adalah dorongan yang menjadi penggerak dalam diri seseorang untuk melakukan seuatu dan mencapai suatu tujuan yaitu untuk mencapai prestasi. Dengan demikian motivasi memiliki peran strategis dalam belajar, maupun saat berakhirnya belajar.

Motivasi belajar secara lebih spesifik yaitu dorongan internal dan eksternal pada siswa yang sedang belajar untuk mengadakan perubahan tingkah laku, pada umumnya dengan beberapa indikator atau unsur yang mendukung. Dorongan yang ada dalam diri siswa ini akan menyertai siswa tersebut dari awal kegiatan belajarnya sampai siswa tersebut merasa cukup untuk mencapai tujuan belajarnya, Uno dan Sutrisno (2016:114). 
1. Jenis-Jenis Motivasi Belajar

a) Motivasi Intrinsik

Motivasi intrinsik merupakan motivasi yang muncul dari dalam diri sendiri, seperti keinginan untuk mendapatkan keterampilan tertentu, mengembangkan sikap untuk berhasil, dan tidak mudah putus asa "Motivasi intrinsik adalah jenis motivasi yang timbul dari dalam diri invidu sendiri tanpa adanya paksaan dorongan orang lain" (2014:19)

b) Motivasi Ekstrinsik

Motivasi ekstrinsik merupakan dorongan yang diperoleh dari luar diri siswi untuk membangun dan menumbuhkan motivasi kepada setiap siswa (Suhan 2014:24)2

\section{Indikator Motivasi Belajar}

Untuk mengetahui seorang peserta didik memiliki motivasi belajar atau tidak, maka perlu diketahui ciri-ciri motivasi pada diri seseorang. Menurut Ahmad Susanto (2019:40) ada beberapa ciri atau indicator motivasi belajar yang dapat di identifikasi, antara lain:

1) Lama waktu yang digunakan untuk kegiatan belajar;

2) Frekuensi kegiatan belajar;

3) Ketetapan dan kelekatan pada tujuan kegiatan;

4) Ketabahan, keuletan, dan kemampuan dalam menggapai kesulitan untuk mencapai tujuan;

5) Pengorbanan (baik dari segi uang, dan tenaga pikiran) untuk mencapai tujuan; 
6) Tingkat aspirasi (cita-cita, sasaran/target, dan idola) yang ingin dicapai;

7) Kualifikasi prestasi yang dicapai dalam kegiatan; dan

8) Arah dan sikapnya terhadap sasaran kegiatan.

3. Faktor-Faktor Yang Memengaruhi Motivasi Belajar

Faktor-Faktor yang memengaruhi motivasi belajar menurut Ahmad Susanto (2019:158) ada enam faktor yang dapat memengaruhi motivasi belajar, yaitu : 1) sikap; 2) kebutuhan; 3) rangsangan; 4) afeksi; 5) kompotensi; dan 6) penguatan.

1) Sikap

Sikap merupakan kombinasi dari konsep, informasi, dan emosi yang di hasilkan di dalam prediposisi untuk merespons orang, kelompok, gagasan, peristiwa, atau objek tertentu secara menyenangkan atau tidak menyenangkan. Sikap memiliki pengaruh kuat terhadap perilaku dan belajar peserta didik, karena sikap itu membantu peserta didik dslsm merasakan dunianya dan memberikan pedoman kepada perilaku yang dapat membantu dalam menjelaskan dunianya.

2) Kebutuhan

Kebutuhan merupakan kondisi yang dialami oleh individu sebagai kekuatan internal yang memandu peserta didik untuk mencaai tujuan. Semakin kuat seseorang merasakan kebutuhan, semakin besar peluangnya untuk mengatasi perasaan yang menekan di dalam memenuhi kebutuhannya. Tekanan ini dapat di terjemahkan kedalam suatu keinginan ketika individu menyadari adanya perasaan dan berkeinginan untuk mencapai tujuan tertentu. 
3) Rangsangan

Rangsangan (stimulus) merupaka perubahan di dalam persepsi atau pengalaman dengan lingkungan yang membuat seseorang bersifat aktif. Stimulus yang unik akan menarik perhatian setiap orang cenderung mempertahankan keterlibatan diri secara aktif terhadap stimulus tersebut. Rangsangan secara langsung membantu memenuhi kebutuhan belajar peserta didik.

4) Afeksi

Konsep afeksi berkaitan dengan pengalaman emosional, kecemasan, kepedulian, dan pemikiran dari individu atau kelompok pada waktu belajar, tidak kegiatan belajar yang terjadi di dalam kevakuman emosional. Siswa merasakan sesuatu saat belajar, dan emosi siswa tersebut dapat memotivasi perilakunya kepada tujuan.

5) Kompotensi

Manusia pada dasarnya memiliki keinginan untuk memperoleh kompotensi dari lingkungannya. Tetapi kompotensi mengasumsikan bahwa siswa secara alamiah berusaha keras berinteraksi dengan lingkungannya secara efektif. Siswa secara instrinsik termotivasi untuk menguasai lingkungan dan mengerjakan tugas-tugas secara berhasil agar menjadi puas. Dalam situasi pembelajaran, rasa kompotensi pada diri siswa itu akan timbul apabila menyadari bahwa pengetahuan atau kompotensi yang di peroleh telah memenuhi standar yang telah di tentukan. 
6) Penguatan

Penguatan merupakan peristiwa yang mempertahankan atau meningkatkan kemungkinan respons. Penggunaan peristiwa penguatan yang efektif, seperti penghargaan terhadap hasil karya siswa, pujian, penghargaan social, dan perhatian, dinyatakan sebagai variabel penting di dalam perancangan pembelajaran.

\section{Fungsi Motivasi Belajar}

Motivasi di perlukan siswa untuk dapat memperoleh hasil yang ingin di capai. Semakin tinggi tingkat motivasi yang dimiliki, maka semakin tinggi pula intensitas belajar yang dilakukan untuk mencapai hasil yang di inginkan. Sehubungan dengan hal itu, menurut Ahmad Susanto (2019:85) fungsi motivasi dalam belajar sebagai berikut :

1) Mendorong manusia untuk berbuat, jadi sebagai penggerak atau motor yang melepaskan energi. Motivasi dalam hal ini merupakan motor penggerak dari setiap kegiatan yang akan di kerjakan.

2) Menentukan arah perbuatan, yakni kearah tujuan yang hendak di capai. Dengan demikian, motivasi dapat memberikan arah dan kegiatan yang harus dikerjakan sesuai dengan rumusan tujuannya.

3) Menyeleksi perbuatan, yakni menetukan perbuatan-perbuatan apa yang harus dikerjakan yang serasi guna mencapai tujuan, dengan menyisihkan perbuatan-perbuatan yang tidak bermanfaat bagi tujuan tersebut. Seseorang siswa yang akan menghadapi ujian dengan harapan dapat lulus, tentu akan melakukan kegiatan belajar dan tidak akan menghabiskan 
waktunya untuk bermain games atau memainkan handphone, sebab tidak serasi dengan tujuan.

\section{Upaya Meningkatkan Motivasi Belajar}

Dalam kegiatan belajar peranan motivasi, baik instrinsik maupun ekstrinsik sangat di perlukan. Dengan motivasi, siswa dapat mengembangkan segala aktivitas dan inisiatif, dapat mengarahkan dan memelihara ketekunan dalam melakukan kegiatan belajar. Motivasi dalam belajar adalah faktor yang penting karena hal tersebut merupakan keadaan yang mendorong keadaan siswa untuk melakukan belajar. Persoalan mengenai motivasi dalam belajar adalah bagaimana cara mengatur agar motivasi dapat ditingkatkan. Dengan demikian dalam kegiatan belajar seorang siswa akan berhasil jika mempunyai motivasi untuk belajar.

\section{Minat Belajar}

\section{Pengertian Minat Belajar}

Sebelum mengetahui minat belajar, maka harus mengetahui pengertian minat dan belajar. Kata minat secara etimologi berasal dari bahasa inggris “interest” yang berarti kesukaan, perhatian (kecenderungan hati pada sesuatu), keinginan. Jadi dalam proses belajar siswa harus mempunyai minat atau kesukaan untuk mengikuti kegiatan belajar yang berlangsung, karena dengan adanya minat akan mendorong siswa untuk menunjukkan perhatian, aktivitasnya dan partisipasinya dalam mengikuti belajar yang berlangsung.

Menurut Ahmad Susanto (2019:61), minat dapat di artikan sebagai suatu kesukaan, kegemaran atau kesenangan akan sesuatu, apabila seseorang melihat 
ciri-ciri atau arti sementara situasi yang di hubungkan dengan keinginankeinginan atau kebutuhan-kebutuhan sendiri. Oleh karena itu, apa saja yang dilihat seseorang barang tentu akan membangkitkan minatnya sejauh apa yang dilihat itu mempunyai hubungan dengan kepentingannya sendiri.

Minat belajar adalah sikap ketaatan dalam kegiatan proses belajar, baik yang menyangkut perencanaan jadwal belajar yang di milikinya maupun inisiatif dirinya sendiri melakukan usaha tersebut dapat bersungguh-sungguh dalam belajar (Andriani dan Rasto, 2019), Adapun Minat belajar adalah salah satu rasa untuk menyukai atau juga tertarik pada satu hal dan aktivitas belajar tanpa ada yang menyuruh untuk belajar (Ricardo dan Meilani, 2017).

Minat belajar siswa merupakan faktor yang sangat penting dalam menunjang tercapainya efektivitas proses belajar, yang pada akhirnya akan berpengaruh terhadap hasil belajar siswa Menurut Slameto (2015: 180) bahwa:

Menurut Bernard (Yulista, 2020:26) menyatakan bahwa minat timbul tidak secara tiba-tiba atau spontan, melainkan timbul akibat kaitannya dengan dari partisipasi, pengalaman, kebiasaan pada waktu belajar atau bekerja. Jadi, jelas bahwa, minat akan selalu terkait dengan persoalan kebutuhan dan keinginan. Dalam praktiknya, minat atau dorongan dalam diri siswa terkait dengan apa dan bagaimana siswa dapat mengaktualisasikan dirinya melalui belajar. Dimana identitas diri memiliki kaitan dengan peluang atau hambatan siswa dapat mengekspresikan potensi atau kreativitas dirinya sebagai sebagai perwujudan dari minat spesifik yang dia miliki. Adapun faktor keturunan dan pengaruh eksternal 
atau lingkungan lebih berkaitan dengan perubahan-perubahan yang terjadi dari minat siswa akibat dari pengaruh situasi kelas, sistem, dan dorongan keluarga.

Minat adalah rasa lebih suka dan rasa keterkaitan pada suatu hal atau aktivitas, tanpa ada yang menyuruh. Minat pada dasarnya adalah penerimaan akan suatu hubungan antara diri sediri dengan sesuatu di luar diri. Semakin kuat atau dekat hubungan tersebut, semakin besar minat.

Berdasarkan berbagai penjelasan diatas, maka diketahui bahwa penting bagi seorang pendidik meningkatkan minat belajar pada siswa. Menurut Simanjuntak (dalam Darmadi, 2017), berikut cara membangkitkan minat belajar:

1) Membuat pembelajaran yang menarik. Misalkan dengan memberikan video atau gambar yang berkaitan dengan materi pelajaran;

2) Mengadakan selingan. Selingan disini di maksud pendidik tidak hanya mengajar dengan ceramah tetapi juga di selingi dengan diskusi, Tanya jawab, memberikan permainan yang berkaitan dengan mata pelajaran dll;

3) Menjelaskan dari yang mudah kesukar dan menjelaskan dari yang konkrit ke abstrak. Hal ini bertujuan untuk membentuk persepsi awal yang baik dalam diri siswa. Selain itu, hal ini ditujukan agar siswa tidak mengalami kebingungan selama belajar.

4) Penggunaan alat peraga. Alat peraga dapat menimbulkan rasa dalam diri siswa sehingga menimbulkan untuk mempelajarinya lebih lanjut. Selain itu,alat peraga ditujukan untuk membuat siswa lebih memahami pelajaran yang sedang dipelajarinya. 
2. Faktor yang Mempengaruhi Minat Belajar

Faktor-faktor yang mempengaruhi minat belajar dapat meningkatkan atau menurunkan minat belajar seseorang. Semakin besar-besar dan positif faktor yang dimiliki seseorang menunjukan semakin tinggi minat orang tersebut, dan sebaliknya. Menurut Sumadi Suryabrata (dalam kahar ikhsa) (2018), faktor yang mempengaruhi minat belajar dibagi menjadi dua yaitu:

\section{a. Faktor internal}

Faktor internal adalah sesuatu yang membuat siswa berminat, yang berasal dari dalam diri sendiri. Faktor internal tersebut antara lain: pemusatan perhatian, keingintahuan, dan motivasi.

1) Perhatian dalam belajar yaitu pengusatan atau konsentrasi.

2) Keingin tahuan adalah perasaan atau sifat yang kuat untuk mengetahui sesuatu dorongan kuat untuk mengetahui lebih banyak tentang sesuatu. Semakin besar keingin tahuan seseorang menunjukan semakin tinggi minat orang tersebut.

3) Motivasi adalah perubahan energi dalam diri seseorang yang ditandai dengan timbulnya perasaan dan reaksi untuk mencapai tujuan

\section{b. Faktor Eksternal}

Faktor eksternal adalah sesuatu yang membuat siswa berminat yang datangnya dari luar diri, seperti: dorongan dari orang tua, dorongan dari pendidikan, tersedianya prasarana dan sarana atau fasilitas dan keadaan lingkungan. 
3. Fungsi Minat Belajar

Makmun Khairani (dalam andry jecseneri, 2018) menjelaskan fungsi minat dalam proses pembelajaran, sebagai berikut:

a. Minat memudahkan terciptanya konsentrasi. Perhatian yang tercipta karena adanya minat sehingga perhatian itu muncul tanpa adanya paksaaan. Hal ini memudahkan perkembanagnya konsentrasi, yaitu pengusatan pemikiran terhadap suatu pelajaran.

b. Minat mencegah gangguan perhatian dari luar. Adanya minat dari dalam diri membuat orang tersebut tidak mudah terganggu dan tidak mudah teralihkan selama belajar.

c. Minat memperkuat melekatnya bahan pelajaran dalam ingatan. Seseorang yang memiliki minat yang tinggi dalam pelajaran maka akan memiliki daya ingat tinggi pula terhadap pelajaran tersebut.

d. Minat memperkecil kebosanan dalam belajar dari dalam diri sendiri. Pengahapusan kebosangan dalam belajar bisa terlaksana dengan menumbuhkan dalam minat belajar dan kemudian minat dapat ditingkat sebesar-besarnya .

\section{Pembelajaran DARING}

\section{Pengertian pembelajaran DARING}

Pandemi Covid-19 memaksa lembaga pendidikan melaksanakan pembelajaran DARING. Pembelajaran DARING biasanya di sebut dengan pembelajaran daring atau juga dapat di sebut e-learning. Menurut Ridwan Sanjaya (2020), pembelajaran DARING adalah metode pembelajaran yang menggunakan 
jaringan untuk berkomunikasi, membaca, dan menulis yang dilakukan pada waktu yang sama tetapi tidak dalam ruang yang sama dengan menggunakan berbagai teknologi dan multimedia (computer, video, audio, smartphone,dsb).

Berbeda dengan Ridwan Sanjaya, newsletter of ODLQC (dalam siahaan, dalam Pupu Saeful Rahmat, 2019) menjelaskan definisi pembelajaran daring dengan contoh, misalkan ada seorang anak yang menggunakan laptopnya dan melakukan akses untuk mengerjakan latihan soal, tetapi tidak ada layanan bantuan belajar seperti bahan materi pembelajaran dari pengajar maupun dukungan layanan belajar bentuk lainnya. Orang tersebut di katakan tidak melaksanakan pembelajaran DARING. Jika orang tersebut menghubungi dan bertanya kepada pengajar, baru dikatakan bahwa orang tersebut melakukan pembelajaran DARING. Berdasarkan contoh ini dapat di simpulkan bahwa pembelajaran DARING adalah proses yang dilakukan oleh pendidik untuk membelajarkan siswa tanpa adanya tatap muka tetapi menggunakan bantuan multimedia dan jaringan agar siswa memperoleh hasil belajar sesuai dengan tujuan pembelajaran.

\section{Keefektifan Pembelajaran DARING}

Pembelajaran yang dilakukan secara DARING ini merupakan satu satunya solusi untuk menekan penyebaran covid 19. Covid 19 merupakan penyakit yang sangat mudah terjadinya penyebaran, dimana virus ini secara khusus menyerang sistem pernafasan manusia Rothan dan Byrareddy, (2020). Pengendalian penyakit menular dapat dilakukan dengan meminimalisir kontak antara orang yang terinfeksi dengan orang yang rentan ditulari. 
Dalam pembelajaran DARING, siswa merasa lebih nyaman untuk bertanya dan mengemukakan pendapat dalam forum yang dilaksanakan secara online Firman \& Sari, (2020:84) menyatakan bahwa pembelajaran online lebih mengarah pada student centered sehingga mampu memunculkan tanggung jawab dan otonomi siswa dalam belajar. Sehingga membuat siswa lebih mampu menumbuhkan kemandirian dalam belajar.

Pupu Saeful Rahmat (2019) menyebutkan tiga syarat kegiatan pembelajaran DARING, yaitu:

1) Kegiatan pembelajaran dilakukan melalui pemanfaatan jaringan internet atau jaringan yang menggunakan LAN atau WAN;

2) Tersedianya dukungan layanan belajar yang dapat di manfaatkan siswa;

3) Tersedianya dukungan layanan belajar yang dapat di manfaatkan siswa apabila mengalami kesulitan.

\section{Manfaat Pembelajaran DARING}

Menurut Widiasworo (dalam Lidia Simanihuruk, dkk, 2019) manfaat dari pembelajaran DARING sebagai berikut :

1) Menciptakan kualitas interaksi yang semakin meningkat;

2) Interaksi pembelajaran berlangsung dimana saja dan kapan saja;

3) Menjangkau siswa dalam cakupan yang luas;

4) Mempermudah pembaharuan dan penyimpangan materi pembelajaran.

4. Kelebihan Pembelajaran DARING

Menurut Budi Harsanto (2014), pembelajaran DARING memiliki kelebihan sebagai berikut : 
1) Mengurangi perjalanan dan biaya perjalanan;

2) Memungkinkan belajar disetiap waktu dan setiap tempat;

3) Menyediakan cara belajar tepat waktu;

4) Memanfaatkan infrastruktur yang ada;

5) Memungkinkan pengiriman materi pembelajaran;

6) Update yang mudah;

5. Kekurangan Pembelajaran DARING

Menurut Lidia Simanihuruk, dkk (2019), kekurangan dari pembelajaran DARING sebagai berikut :

1) Kurangnya interaksi tatap muka antara siswa dengan pendidik dan antar siswa dengan siswa;

2) Pembelajaran yang dilakukan cenderung ke pelatihan bukan pendidikan;

3) Pengajar di tuntut lebih menguasai teknik pembelajaran dengan menggunakan TIK;

4) Belum meratanya fasilitas internet;

5) Kurangnya sumber daya manusia yang memiliki keahlian mengoperasikan computer;

6) Informasi yang di peroleh memiliki variasi kualitas dan keakuratan informasi;

7) Sarana prasarana yang tidak mendukung menyebabkan kesulitan mengakses grafik, gambar, dan video. 


\section{Pembelajaran DARING di Tengah Covid-19}

Covid-19 menyebabkan pembelajaran di tiadakan dan memaksa lembaga. pendidikan melaksanakan pembelajaran DARING. Padahal selama ini pembelajaran terbiasa di lakukan secara tatap muka. Hal ini tentu saja, membuat ketidaknyamanan bagi pendidik maupun siswa. Dalam pelaksanaannya, pembelajaran daring masih memiliki hambatan.

Menurut Yohanes Enggar Harususilo (2020), mahasiswa menyatakan kesulitan mengikuti pembelajaran DARING karena harus mengeluarkan biaya lebih untuk membeli kuota demi terlaksananya pembelajaran daring. Berdasarkan penelitian yang dilakukan oleh Jamaluddin, D., Ratnasih, T., Gunawan, H., \& Paujiah, E. (2020), diketahui bahwa manusia mengalami hambatan dan kesulitan pembelajaran DARING, yaitu banyaknya tugas, terbatasnya kuota, penguasaan IT yang masih terbatas baik bagi pendidik maupun siswa (siswa), dan jaringan internet yang tidak stabil.

Penelitian lain yang di lakukan oleh Firman F., \& Rayu, S. (2020), menjelaskan bahwa siswa mengalami kesulitan dalam membeli kuota, terbatasnya jaringan internet dan kurang memahami materi pembelajaran yang di berikan guru. Selain hambatan dalam pelaksanaan pembelajaran DARING, penelitian Firman F., \& Rayu, S. (2020) juga menjelaskan bahwa siswa merasa puas dengan fleksibilitas dalam pelaksanaan pembelajaran DARING dan juga siswa juga merasakan lebih nyaman serta percaya diri untuk mengemukakan pendapat atau bertanya dalam forum pembelajaran DARING. 


\section{B. Penelitian Relevan}

Kajian penelitian yang relevan dengan penelitian yang berjudul "Pengaruh motivasi terhadap minat belajar DARING siswa SDN Pannara Kota Makassar adalah sebagai berikut :

- Penelitian yang berjudul "Pengaruh Minat Belajar Dan Motivasi Belajar Terhadap Prestasi Belajar Mahasiswa Program Studi Pendidikan Akuntansi Angkatan 2008 Universitas Negeri Yogyakarta”. Penelitian tersebut merupakan penelitian deskriptif kuantitatif yang menggunakan data angket dan dokumentasi. Hasil penelitian menunjukkan koefisien regresi ${ }^{\circledR}$ sebesar 0,278 yang berarti minat belajar dan motivasi belajar secara bersama-sama mempengaruhi prestasi belajar sebesar 27,8\% dengan nilai Ghitung sebesar 3,678 dengan tingkat signifikansi uji Ftabel sebesar 0,029 penelitian ini sama-sama menggunakan variabel motivasi belajar dan minat belajar sebagai variabel bebas, untuk variabel terikat menggunakan variabel prestasi belajar.

\section{Kerangka Pikir}

Berdasarkan hasil penelitian di SDN Pannara Kota Makassar pada 25 Juni 2021 diperoleh informasi bahwa siswa memiliki tingkat motivasi belajar dan minat belajar DARING yang berbeda-beda, hal itu berpengaruh pula pada motivasi belajar dan minat belajar DARING siswa dalam mengikuti kegiatan belajar, Cara mengajar guru juga berpengaruh pada ketertarikan siswa dalam mengikuti pembelajaran, motivasi belajar dan minat belajar DARING sangat berperan penting dalam proses pembelajaran, dimana pembelajaran dilakukan 
secara DARING guna meningkatkan minat belajar siswa, dan orang tua turut bekerja sama untuk berperan dalam pembelajaran DARING siswa, sehingga apa yang di inginkan akan berjalan dengan baik.

Berdasarkan hasil penelitian di SDN Pannara Kota Makassar peneliti menemukan beberapa masalah yaitu pada tanggal 25 Juni 2021 salah satu masalah yang ditemukan motivasi belajar dan minat belajar DARING siswa, penulis tertarik untuk melakukan penelitian berdasarkan hasil observasi yang telah di lakukan, melihat kendala di SDN Pannara Kota Makassar.

Motivasi belajar adalah memberikan daya dorongan sehingga sesuatu yang di motivasi tersebut dapat bergerak. Jadi peran motivasi dalam pembelajaran yaitu sebagai pendorong siswa untuk giat dalam belajar dan mencapai tujuan yang diharapkan. Seseorang yang mempunyai motivasi belajar yang tinggi akan memperoleh hasil minat belajar tinggi pula, Motivasi tersebut dapat dilandasi dengan ketekunan dalam belajar, menghadapi persoalan di dalam tugas, menyelesaikan tugas tepat waktu, tidak mudah bosan dengan tugas yang di lakukan, dan selalu memberikan hasil yang maksimal dalam setiap tugas yang di berikan, keinginan untuk memiliki nilai yang bagus.

Berdasarkan uraian diatas dapat di ketahui bahwa adanya pengaruh motivasi terhadap minat belajar DARING siswa. Dengan begitu untuk mempermudah memahami alur penelitian ini, maka penulis membuat bagan kerangka pikir. Sehingga dengan melihat gambar ini, dapat di ketahui apa saja yang peneliti lakukan di dalam memecahkan permasalahan yang di hadapi yaitu : 
"Pengaruh Motivasi Terhadap Minat Belajar DARING Siswa SDN Pannara Kota Makassar".

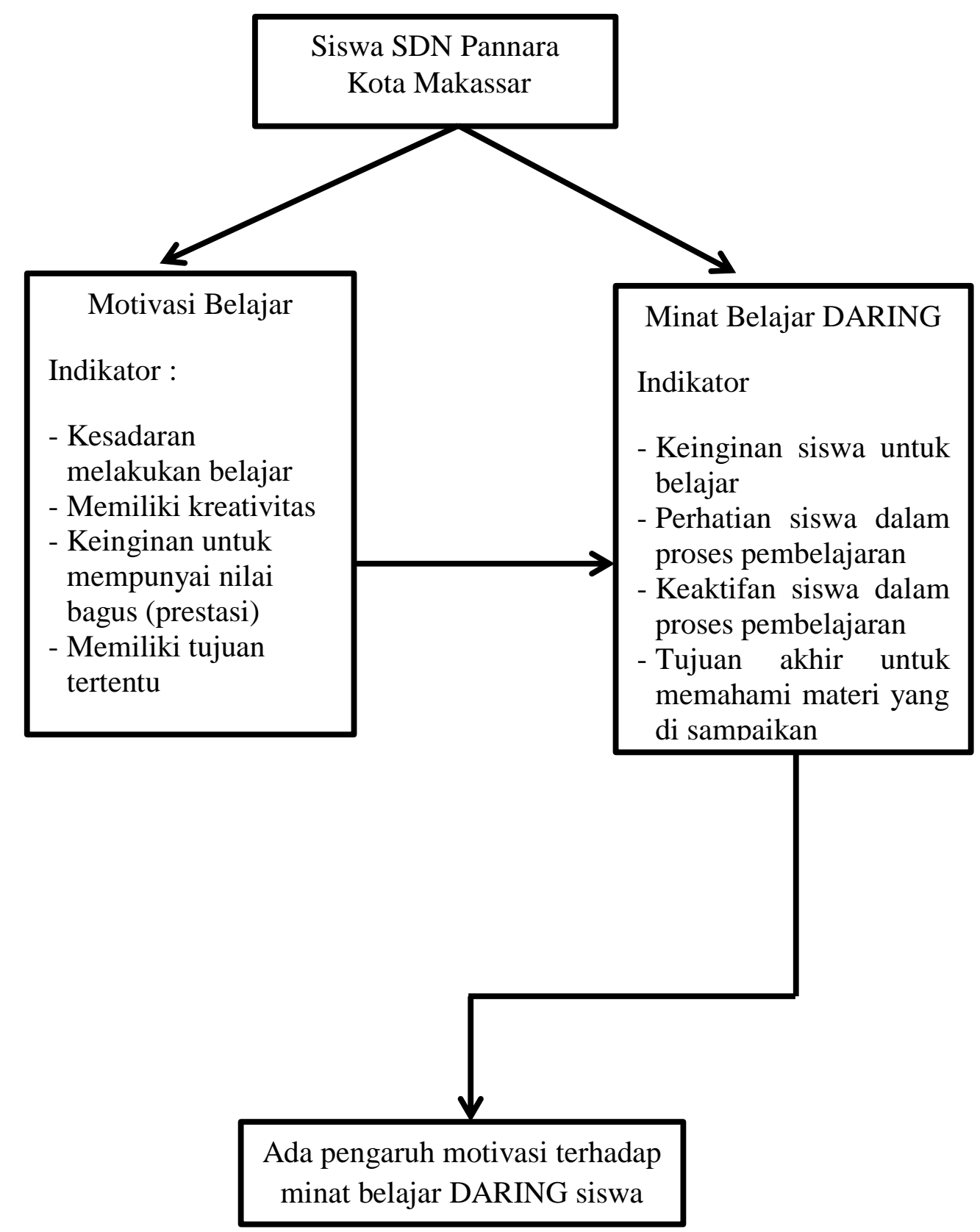

Bagan 2.1 Skema Kerangka Pikir 


\section{Hipotesis Penelitian}

Berdasarkan dari uraian tinjauan pustaka dan kerangka pikir yang telah diuraikan, maka dirumuskan hipotesis penelitian ini adalah terdapat Pengaruh Motivasi Terhadap Minat Belajar DARING Siswa SDN Pannara Kota Makassar 


\section{BAB III}

\section{METODE PENELITIAN}

\section{A. Jenis Dan Desain Penelitian}

Penelitian ini merupakan jenis penelitian ex post facto artinya penelitian yang di lakukan untuk meneliti peristiwa yang telah terjadi, penelitian ini termasuk dalam penelitian kuantitatif yang artinya semua data di wujudkan dalam bentuk angka-angka dan analisisnya menggunakan analisis statistik.

Desain Penelitian Ex post facto menurut Sukmadinata Nana Syaodih (2016) adalah penelitian hubungan sebab-akibat yang tidak dimanipulasi atau diberi perlakuan. Penelitian hubungan sebab-akibat dilakukan terhadap program, kejadian yang telah berlangsung atau telah terjadi. Penelitian Ex Post Facto yaitu suatu penelitian yang digunakan untuk mengetahui suatu kejadian peristiwa yang telah terjadi antara dua variabel atau lebih tanpa ada upaya untuk mempengaruhi variabel tersebut sehingga tidak terdapat manipulasi variabel (Abustang, P. B. 2018: 80). Penelitian ini dilakukan untuk melihat apakah ada pengaruh motivasi belajar $(\mathrm{X})$ terhadap minat belajar DARING (Y) dengan desain penelitian sebagai berikut:

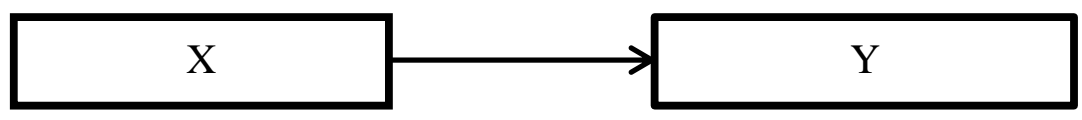

Bagan 3.1 Desain Penelitian, Jusmawati (2018)

Keterangan :

$\mathrm{X}=$ Variabel Bebas (Motivasi Belajar)

$\mathrm{Y}=$ Variabel Terikat (Minat Belajar DARING) 


\section{B. Waktu dan Lokasi penelitian}

Penelitian ini dilakukan di SDN Pannara yang beralamatkan Jalan Antang Raya, Kecamatan Manggala Kota Makassar Provinsi Sulawesi Selatan. Penelitian di laksanakan pada bulan Juni 2021.

\section{Variabel Penelitian dan Definisi Operasional}

1. Variabel Penelitian

Variabel penelitian adalah sifat dan nilai dari seseorang yang mempunyai variasi berbeda beda yang ditetapkan oleh peneliti untuk dipelajari dan kemudian ditarik kesimpulannya. Dalam penelitian ini terdiri dari dua variabel yaitu variabel independen (bebas) yaitu Motivasi belajar (diberi simbol X) dan Variabel dependen (terikat) yaitu Minat Belajar DARING (diberi simbol Y).

a. Variabel bebas (Independen)

Variabel bebas (X) adalah variabel yang mempengaruhi variabel lain atau kata lain (variabel bebas) dalam penelitian ini adalah motivasi belajar.

b. Variasi terikat (Dependen)

Variasi terikat (Y) adalah variabel yang menjadi akibat yang di pengaruhi oleh variabel bebas. Variabel terikat (Y) dalam penelitian ini adalah minat belajar DARING.

2. Definisi Operasional

Bagaimana peneliti akan menjelaskan tentang suatu variabel yang akan diteliti, Agar penelitian ini berjalan dengan lancar dan sesuai dengan yang 
diharapkan, maka perlu adanya definisi operasional variabel untuk menghindari kesalah pahaman.

a. Motivasi belajar : merupakan unsur yang sangat penting dalam proses pembelajaran. Karena tanpa disadari bahwa motivasi belajar dapat berpengaruh dengan aktif dan pasifnya siswa dalam mengikuti proses pembelajaran didalam kelas.

b. Minat belajar DARING : adalah rasa lebih suka dan rasa keterkaitan pada suatu hal atau aktivitas, tanpa ada yang menyuruh. Minat pada dasarnya adalah penerimaan akan suatu hubungan antara diri sediri dengan sesuatu di luar diri. Semakin kuat atau dekat hubungan tersebut. Minat belajar daring adalah suatu metode pembelajaran yang menggunakan jaringan untuk berkomunikasi, membaca, dan menulis yang dilakukan pada waktu yang lama tetapi tidak dalam ruang yang sama dengan menggunakan berbagai teknologi dan multimedia (computer, video, audio, smartphone,dsb).

\section{Populasi, Sampel Dan Teknik Pengambilan Sampel}

1. Populasi Penelitian

Populasi dalam penelitian ini adalah seluruh siswa kelas IV, V, VI SDN

Pannara Kota Makassar. Berdasarkan data yang diperoleh dari kepala sekolah SDN Pannara pada Tahun Ajaran 2020/2021 diperoleh jumlah keseluruhan siswa kelas IV adalah 56 Siswa V adalah 66 siswa dan kelas VI adalah 72 Siswa Adapun populasi dari sekolah tersebut dapat ditunjukkan pada tabel di bawah ini: 
Tabel 3.1 Populasi Siswa Kelas IV,V,VI SDN Pannara

\begin{tabular}{cccc}
\hline Kelas & \multicolumn{2}{c}{ Jumlah } & Jumlah Keseluruhan \\
\cline { 2 - 3 } & A & B & \\
\hline IV & 30 & 26 & 56 \\
\hline V & 30 & 36 & 66 \\
\hline VI & 36 & 36 & 72 \\
\hline & Jumlah & & 194
\end{tabular}

Sumber: SDN Pannara Kota Makassar Tahun Ajaran 2019/2020

Tabel 3.2 Sampel Siswa Kelas V SDN Pannara

\begin{tabular}{cccc}
\hline \multirow{2}{*}{ Kelas } & \multicolumn{2}{c}{ Jumlah } & Jumlah Keseluruhan \\
\cline { 2 - 3 } & Laki-laki & Perempuan & \\
\hline V & 31 & 35 siswa & 66 siswa \\
\hline \multicolumn{3}{c}{ Jumlah Keseluruhan Murid } & 66 siswa \\
\hline Sumber : SDN Pannara Kota Makassar Tahun Ajaran 2019/2020
\end{tabular}

2. Sampel Penelitian

Sampel adalah kelompok kecil yang secara nyata kita teliti dan tarik kesimpulan dari padanya (Sukmadinata, 2016: 250). Jumlah sampel dalam penelitian ini yaitu 66 siswa.

3. Teknik Pengambilan Sampel

Pengambilan sampel pada penelitian ini menggunakan teknik secara acak (random sampling), teknik acak adalah teknik pengambilan sampel dimana semua individu dalam populasi baik secara sendiri-sendiri atau bersama-sama diberi kesempatan yang sama untuk dipilih sebagai anggota sampel. jumlah populasi keseluruhan adalah 194 siswa, namun peneliti mengambil sampel dengan jumlah 66 siswa.

\section{E. Instrumen Penelitian}

Instrumen penelitian adalah suatu alat yang digunakan untuk mengumpulkan data-data yang diperlukan dalam penelitian, Nurhadifah Amaliyah 
(2019). Instrument digunakan untuk mempermudah dalam penelitian dan hasilnya lebih cermat, lengkap dan sistematis sehingga lebih mudah diolah.

Adapun kisi-kisi instrumen penelitian adalah sebagai berikut :

Tabel 3.3 Kisi-Kisi Instrumen motivasi belajar

\begin{tabular}{cccc}
\hline No. & Indikator & No item & Jumlah \\
\hline 1. & $\begin{array}{c}\text { Saya belajar karena kegiatan } \\
\text { yang menyenangkan }\end{array}$ & $1,2,3$ & 3 \\
\hline 2. & Memiliki kreativitas & $4,5,6$ & 3 \\
\hline 3. & $\begin{array}{c}\text { Keinginan untuk } \\
\text { mempunyai nilai bagus } \\
\text { (prestasi) }\end{array}$ & $7,8,9,10$ & 4 \\
\hline & Memiliki tujuan tertentu & $11,12,13$ & 3 \\
\hline 4. & Mencari solusi belajar & $14,15,16$ & 3 \\
\hline 5. & Tidak mudah bosan & $17,18,19$ & 3 \\
\hline 6. & Selalu mengerjakan tugas \\
dengan maksimal & 20,21, & 2 \\
\hline 7. & Jumlah & $\mathbf{2 1}$ \\
\hline
\end{tabular}

Sumber : Lampiran 1 Halaman 61

Tabel 3.4 Kisi-Kisi Instrumen Minat Belajar Daring

\begin{tabular}{rccc}
\hline No & Indikator & No item & Jumlah \\
\hline 1. & $\begin{array}{c}\text { Keinginan siswa untuk } \\
\text { belajar }\end{array}$ & $1,2,3$ & 3 \\
\hline 2. & $\begin{array}{c}\text { Ketertarikan siswa terhadap } \\
\text { belajar daring }\end{array}$ & 4,5 & 2 \\
\hline 3. & $\begin{array}{c}\text { Perhatian siswa dalam } \\
\text { proses pembelajaran. }\end{array}$ & $6,7,8$ & 2 \\
\hline 4. & $\begin{array}{c}\text { Keaktifan siswa dalam } \\
\text { proses pembelajaran } \\
\text { Tujuan akhir untuk } \\
\text { memahami materi yang di } \\
\text { sampaikan }\end{array}$ & 9,10 & 3 \\
\hline \multicolumn{3}{c}{ Jumlah } \\
\hline
\end{tabular}

Sumber : Lampiran 1 Halaman 61

Responden di minta untuk memilih kategori jawaban yang telah tersedia dengan memberikan tanda $(\sqrt{ })$ pada jawaban yang dipilihnya angket untuk mengukur pengaruh motivasi terhadap minat belajar daring siswa menggunakan 
skala likert, Sistem penskoran untuk skala Likert pada setiap pernyataan positif yaitu subjek akan mendapat skor 4 jika menjawab selalu, skor 3 jika menjawab sering, skor 2 jika menjawab kadang-kadang, dan skor 1 jika menjawab tidak pernah. Sedangkan untuk pernyataan negatif, subjek akan memperoleh skor 1 jika menjawab selalu, skor 2 jika memilih sering, skor 3 jika memilih jarang, dan skor 4 jika memilih tidak pernah.

Tabel 3.5 Skor Untuk Setiap Butir Pernyataan Pada Skala Litert

\begin{tabular}{ccccc}
\hline Kategori Pernyataan & \multicolumn{5}{c}{ Alternatif Jawaban } \\
\cline { 2 - 5 } & Selalu & Sering & Kadang-Kadang & Tidak Pernah \\
\hline Positif & 4 & 3 & 2 & 1 \\
\hline Negatif & 1 & 2 & 3 & 4 \\
\hline
\end{tabular}

Sumber : Dwi Elmi Setyorini (2016)

1. Angket

Angket yang digunakan dalam penelitian ini adalah angket tertutup. Untuk memperoleh data yang diperlukan dalam penelitian ini, digunakan teknik yaitu seperangkat instrumen berupa angket model skala Likert. Responden diharapkan untuk memberikan jawaban menurut skala tersebut. Responden yang akan diberikan angket oleh peneliti adalah siswa kelas V SDN Pannara Kota Makassar.

2. Dokumentasi

Teknik dokumentasi ini dilakukan agar dapat mendukung hasil proses pengumpulan data. Adapun data tertulis yang diperoleh melalui teknik dokumentasi ini yaitu berupa dokumen atau naskah profil sekolah, sejarah sekolah, identitas siswa, guru, serta foto-foto selama meneliti, sebagai bukti penelitian di SDN Pannara Kota Makassar. 


\section{F. Teknik Pengumpulan Data}

Teknik pengumpulan data merupakan langkah yang paling utama dalam penelitian, karena tujuan utama dalam penelitian adalah mendapatkan data. Pengumpulan data dapat dihimpun dari berbagai tempat, dari berbagai sumber dan dan dengan berbagai cara (Indrawan Rully dan Poppy Yaniawati, 2014). Teknik pengumpulan data yang digunakan dalam penelitian ini yakni angket atau kuesioner, wawancara atau interview, observasi dan dokumentasi. Adapun prosedur pengumpulan data yang harus ditempuh dalam penelitian ini adalah:

1. Tahap Persiapan

a. Uji Validitas

1) Validitas Pakar

Validitas pakar digunakan untuk menguji instrumen yang disusun benar mewakili aspek yang diukur sehingga layak untuk digunakan, maka instrumen terlebih dahulu diuji kualitasnya secara teoritis sebelum diuji cobakan. Pengujian secara teoritis dilakukan oleh dua orang ahli pada bidangnya atau pakarnya. Validitas angket motivasi belajar dan minat belajar DARING divalidasi oleh dosen ahli Universitas Megarezky, yaitu: R. Supardi, S.Pd., M.Pd. (Dosen PGSD Universitas Megarezky) dan Cayati, S.Pd., M.Pd. (Dosen Universitas Megarezky).

2) Validitas Butir

Instrumen sudah memadai dari segi validitas teoritis, maka selanjutnya diuji cobakan kepada responden di luar populasi. Instrumen diuji cobakan di kelas 5A dan 5B SD Inpres Pannara Kota Makassar. 
Motivasi Belajar diukur menggunakan angket yang terdiri dari 30 butir pernyataan positif maupun negatif, sedangkan minat belajar DARING diukur menggunakan angket yang terdiri dari 20 butir pernyataan positif dan negatif dengan jumlah responden 30 siswa (lampiran halaman). Setelah melakukan uji coba instrumen persiapan selanjutnya adalah melakukan uji validitas dengan bantuan Microsoft Ecxel kemudian diolah di SPSS 21 For windows.

Berdasarkan jumlah instrumen motivasi belajar dalam penelitian adalah sebanyak 30 butir instrumen yang terdiri dari pernyataan positif maupun negatif. Setelah dilakukan uji coba terhadap 30 responden dan telah dilakukan analisis validasi butir angket dengan taraf signifikansi 0,05, maka diperoleh hasil validasi sebanyak 21 item pernyataan valid atau item soal valid, adapun hasil uji validitas motivasi belajar sebagai berikut :

Tabel 3.6 Hasil Uji Validitas Uji Coba Angket Motivasi Belajar

\begin{tabular}{|c|c|c|c|}
\hline $\begin{array}{c}\text { No. } \\
\text { Item }\end{array}$ & r hitung & r table & Validitas \\
\hline 1 & 0.384 & 0.361 & Valid \\
\hline 2 & 0.027 & 0.361 & Tidak Valid \\
\hline 3 & 0.623 & 0.361 & Valid \\
\hline 4 & 0.406 & 0.361 & Valid \\
\hline 5 & 0.696 & 0.361 & Valid \\
\hline 6 & 0.616 & 0.361 & Tidak Valid \\
\hline 7 & 0.348 & 0.0361 & Valid \\
\hline 8 & 0.414 & 0.361 & Valid \\
\hline 9 & 0.674 & 0.361 & Valid \\
\hline 10 & 0.266 & 0.361 & Valid \\
\hline 11 & 0.578 & 0.361 & Valid \\
\hline 12 & 0.452 & 0.361 & Valid \\
\hline 13 & 0.466 & 0.361 & Valid \\
\hline 14 & 0.537 & 0.361 & Valid \\
\hline 15 & 0.643 & 0.361 & 0.361 \\
\hline 16 & 0.742 & & \\
\hline
\end{tabular}




\begin{tabular}{|l|c|c|c|}
\hline 17 & 0.403 & 0.361 & Valid \\
\hline 18 & 0.349 & 0.361 & Tidak Valid \\
\hline 19 & 0.487 & 0.361 & Valid \\
\hline 20 & 0.212 & 0.361 & Tidak Valid \\
\hline 21 & 0.527 & 0.361 & Valid \\
\hline 22 & 0.692 & 0.361 & Valid \\
\hline 23 & 0.800 & 0.361 & Valid \\
\hline 24 & 0.537 & 0.361 & Tidak Valid \\
\hline 25 & 0.268 & 0.361 & Valid \\
\hline 26 & 0.549 & 0.361 & Tidak Valid Valid \\
\hline 27 & 0.244 & 0.361 & Valid \\
\hline 28 & 0.315 & 0.361 & Tidak Valid \\
\hline 29 & 0.66 & 0.361 & 0.361 \\
\hline 30 & 0.258 & & \\
\hline
\end{tabular}

Sumber : Lampiran 6 Halaman 72

Berdasarkan jumlah instrumen minat belajar DARING dalam penelitian

adalah sebanyak 20 butir instrumen yang terdiri dari pernyataan positif dan negatif. Setelah dilakukan uji coba terhadap 30 responden dan telah dilakukan analisis validasi butir angket dengan taraf signifikansi 0,05, maka diperoleh hasil validasi sebanyak 13 item yang valid, sedangkan 7 item lainnya tidak valid. Berdasarkan uji validitas empiris tersebut, maka angket yang dapat digunakan dalam penelitian ini adalah sebanyak 13 item, sedangkan 7 butir angket yang dinyatakan tidak valid tidak digunakan dalam penelitian ini, adapun hasil uji validasi minat belajar DARING sebagai berikut :

Tabel 3.7 Hasil uji validasi minat belajar DARING

\begin{tabular}{|c|c|c|c|}
\hline $\begin{array}{c}\text { No. } \\
\text { Item }\end{array}$ & r hitung & r table & Validitas \\
\hline 1 & 0.537 & 0.361 & Valid \\
\hline 2 & 0.535 & 0.361 & Valid \\
\hline 3 & 0.399 & 0.361 & Valid \\
\hline 4 & 0.322 & 0.361 & Tidak Valid \\
\hline 5 & 0.387 & 0.361 & Valid \\
\hline 6 & 0.499 & 0.361 & Valid \\
\hline 7 & 0.448 & 0.361 & Valid \\
\hline 8 & 0.492 & 0.361 & \\
\hline
\end{tabular}




\begin{tabular}{|c|c|c|c|}
\hline 9 & 0.689 & 0.361 & Valid \\
\hline 10 & 0.458 & 0.361 & Valid \\
\hline 11 & 0.610 & 0.361 & Valid \\
\hline 12 & 0.141 & 0.361 & Tidak Valid \\
\hline 13 & 0.439 & 0.361 & Tidak Valid \\
\hline 14 & 0.288 & 0.361 & Tidak Valid \\
\hline 15 & 0.248 & 0.361 & Tidak Valid \\
\hline 16 & 0.245 & 0.361 & Tidak Valid \\
\hline 17 & 0.350 & 0.361 & Valid \\
\hline 18 & 0.558 & 0.361 & Valid \\
\hline 19 & 0.430 & 0.361 & Tidak Valid \\
\hline 20 & 0.315 & 0.361 & \\
\hline
\end{tabular}

Sumber : Lampiran 10 Halaman 78

b. Uji Reliabilitas

Uji reliabilitas bertujuan untuk melihat kuesioner memiliki konsistensi jika pengukuran dilakukan secara berulang-ulang, oleh karena itu uji reliabilitas dilakukan setelah uji validitas. Uji reliabilitas hanya dilakukan terhadap instrumen yang memiliki validitas dan dikatakan reliabel jika pengukuran terhadap objek yang sama secara berulang-ulang dengan menggunakan instrumen yang sama memberikan hasil yang sama.

Standar yang digunakan dalam menentukan reliabel suatu instrumen penelitian umumnya dalah perbandingan antara nilai rhitung dan rtabel pada taraf kepercayaan $95 \%$ atau tingkat signifikansi $5 \%$. Tingkat reliabilitas dengan menggunakan metode alpha-cronbach $>0,70$ diukur berdasarkan skala alpha 0 sampai dengan 1 . Tingkat skala tersebut dapat dikelompokkan kedalam 5 kelas yang dapat di interprestasikan. 
Tabel 3.8 Tingkat Reliabilitas Berdasarkan Nilai Alpha

\begin{tabular}{cl}
\hline Alpha & Tingkat Realibitas \\
\hline 0,00 s.d 0,20 & Kurang Reliabel \\
$>0,20$ s.d 0,40 & Agak Reliabel \\
$>0,40$ s.d 0,60 & Cukup Reliabel \\
$>0,60$ s.d 0,80 & Reliabel \\
$>0,80$ s.d 1,00 & Sangat Reliabel \\
\hline
\end{tabular}

Sumber: Arikunto, 2014: 319

Analisis uji reliabilitas dalam penelitian ini menggunakan software SPSS 21 for windows. Hasil uji reliabilitas dengan menggunakan software SPSS 21 for windows diperoleh nilai Alpha Cronbach sebesar 0,853 untuk variabel motivasi belajar dengan kriteria sangat reliabel dan nilai Alpha Cronbach sebesar 0,722 untuk minat belajar DARING dengan kriteria reliabel.

Hasil uji reliabilitas untuk angket motivasi belajar dapat dilihat pada tabel berikut:

Tabel 3.9 Hasil Uji Reliabilitas Motivasi Belajar Reliability Statistics

\begin{tabular}{cc} 
Cronbach's Alpha & N of Items \\
\hline .853 & 30
\end{tabular}

Sumber: Lampiran 7 halaman 73

Berdasarkan tabel 3.9 diperoleh reliabilitas dengan nilai alpha sebesar 0,853 dan nilai ini lebih besar dari rtabel $=0,361$ maka instrumen dinyatakan reliabel dengan kriteria sangat reliabel. Output dapat dilihat pada lampiran 7 halaman 73. Sedangkan hasil uji reliabilitas angket minat belajar daring dapat dilihat pada tabel berikut:

Tabel 3.10 Hasil Uji Reliabilitas Minat Belajar DARING Reliability Statistics

\begin{tabular}{cc} 
Cronbach's Alpha & N of Items \\
\hline .722 & 20
\end{tabular}

Sumber: Lampiran 10 halaman 78 
Berdasarkan tabel 3.10 diperoleh reliabilitas dengan nilai alpha sebesar 0,722 dan nilai ini lebih besar dari rtabel $=0,361$ maka instrumen dinyatakan reliabel dengan kriteria sangat reliabel. Output dapat dilihat pada lampiran 10 halaman 78. Setelah melakukan uji validitas dan reliabilitas instrumen, persiapan lainnya yaitu menyelesaikan urusan administrasi seperti surat izin penelitian mulai dari tingkat prodi dan juga lembaga pendidikan yang menjadi objek penelitian yaitu di SDN Pannara Kota Makassar

2. Tahap Pelaksanaan

Dalam rangka usaha pengumpulan data, maka penulis menggunakan beberapa metode pengumpulan data sebagai berikut:

a. Untuk memperoleh data yang diperlukan dalam penelitian ini, digunakan teknik yaitu seperangkat instrumen berupa angket model skala likert yang diberikan kepada responden yaitu siswa SDN Pannara Kota Makassar, instrumen yang dibagikan adalah instrumen yang sudah valid dan reliabel. Motivasi Belajar diukur menggunakan angket yang terdiri dari 21 butir pernyataan positif maupun negatif yaitu soal nomor $1,2,3,4,5,6,7,8,9,10,11,12,13,14,15,16$, 17, 18, 19, 20, 21, (lampiran 2 halaman 62). Sedangkan minat belajar DARING diukur menggunakan angket yang terdiri dari 20 butir pernyataan positif maupun negatif yaitu soal nomor 1, 2, 3, 4, $5,6,7,8,9,10,11,12,13$. 
b. Dokumentasi dilakukan untuk mengumpulkan data selama responden mengisi angket yang diberikan sebagai bukti akurat bahwa peneliti benar telah melakukan penelitian SDN Pannara Kota Makassar

\section{G. Teknik Analisis Data}

Dalam penelitian kuantitatif, analisis data merupakan kegiatan setelah data dari seluruh responden atau sumber data lain terkumpul. Data yang diperoleh Data yang diperoleh dianalisis dengan menggunakan teknik analisis statistik :

\section{Analisis Deskriptif}

Dalam penelitian ini, analisis deskriptif di gunakan untuk mendeskripsikan setiap variabel penelitian yaitu motivasi belajar, minat belajar DARING siswa motivasi dan minat belajar DARING sangat di perlukan karena motivasi sebagai daya penggerak untuk mencapai tujuan tertentu. hasil analisis statistic deskriptif meliputi penyajian data, tabel dan perhitungan persentase.

Setelah dilakukan penghitungan skor maka dilakukan penggolongan kecenderungan Motivasi belajar siswa, masing-masing motivasi belajar dihitung jumlah siswanya dan dibandingkan dengan jumlah siswa seluruhnya, dilakukan pemberian tingkatan motivasi belajar siswa (motivasi belajar, minat belajar DARING). Peneliti menggunakan kriteria atau ukuran untuk dijadikan patokan yaitu kriteria penilaian lima kategori menurut Suharsimi Arikunto dalam Amin Pujiarti (2013) 
a. Gambaran Motivasi Belajar

Berikut merupakan tabel klarifikasi motivasi belajar, dalam tabel ini dapat di lihat penempatan interval skor berdasarkan kategori yang di berikan terhadap motivasi belajar.

Tabel 3.11 Kategori Motivasi Belajar

\begin{tabular}{lcc}
\hline No. & Interval & Kategori \\
\hline 1. & $81-100$ & Sangat berperan \\
\hline 2 & $61-80$ & Berperan \\
\hline 3 & $41-60$ & Cukup berperan \\
\hline 4 & $21-40$ & Kurang berperan \\
\hline 5 & $0-20$ & Tidak berperan \\
\hline
\end{tabular}

Sumber : Lampiran 20 Halaman 101

Tabel diatas merupakan keterangan klarifikasi motivasi belajar yang di kategorikan dalam interval skor. Sangat berperan jika skor (81-100), berperan jika skor (61-80)), cukup berperan jika skor (41-60), kurang berperan jika skor (21-40), dan tidak berperan jika skor (0-20)

b. Gambaran minat belajar DARING

Berikut merupakan tabel klarifikasi minat belajar DARING, dalam tabel ini dapat dilihat penempatan interval skor berdasarkan kategori yang diberikan terhadap minat belajar DARING.

Tabel 3.12 Kategori Minat belajar DARING

\begin{tabular}{lcc}
\hline No. & Interval & Kategori \\
\hline 1. & $81-100$ & Sangat termotivasi \\
\hline 2. & $61-80$ & Termotivasi \\
\hline 3. & $41-60$ & Cukup termotivasi \\
\hline 4. & $21-40$ & Kurang termotivasi \\
\hline 5. & $0-20$ & Tidak termotivasi \\
\hline
\end{tabular}

Sumber : Lampiran 21 Halaman 102 
Tabel diatas merupakan keterangan klarifikasi minat belajar DARING yang di kategorikan dalam interval skor. Sangat termotivasi jika skor (81-100), termotivasi jika skor (61-80), cukup termotivasi jika skor (41-60), kurang termotivasi jika skor (21-40), dan tidak termotivasi jika skor (0-20).

\section{Analisis Inferensial}

Analisis statistik inferensial menggunakan teknik regresi sederhana untuk mengetahui ada tidaknya pengaruh motivasi terhadap minat belajar DARING siswa SDN Pannara Kota Makassar. Analisis tersebut menggunakan software SPSS 21 for Windows. Kriteria pengujian yang digunakan adalah $\operatorname{sig}<\alpha$ dengan taraf $\alpha=0,05$. Pengujian hipotesis secara inferensial sebelum dilakukan maka terlebih dahulu akan dilakukan uji normalitas dan uji linearitas. Sebelum melakukan analisis tersebut, terlebih dahulu melakukan uji prasyarat.

a. Analisis Prasyarat

Analisis prasyarat meliputi Uji normalitas, uji homogenitas, dan uji linearitas

1) Uji Normalitas

Uji Normalitas dilakukan untuk mengetahui tentang keadaan sampel yang diambil apakah berasal dari populasi yang berdistribusi normal. Uji normalitas merupakan langkah awal dalam menganalisis data secara spesifik. Pengujian data menggunakan One-Sample Kolmogorov-Smirnov Test dibantu dengan software SPSS 21 for windows dan data hasil dari 
sampel akan berdistribusi normal dengan kriteria sig $>\alpha$ dengan taraf $\alpha=$ 0,05 .

2) Uji Homogenitas

Uji Homogenitas data menggunakan Levene's Test for Equality of Variance dibantu dengan software SPSS 21 for windows dengan criteria pengujian yang digunakan adalah $\operatorname{sig}>\alpha$ dengan taraf $\alpha=0,05$.

3) Uji Linieritas

Uji Linieritas digunakan dengan tujuan untuk mengetahui apakah dua variabel yang akan dianalisis menunjukkan hubungan linear atau tidak secara signifikan dengan bantuan software SPSS 21 for windows dengan kriteria pengujian yang digunakan adalah sig $>\alpha$ dengan taraf $\alpha=0,05$.

b. Uji Hipotesis Statistik (Uji F)

Uji F menggunakan software SPSS 21 for windows. F hitung > F tabel, $\mathrm{P}$ Value $\alpha<0,05$ dengan taraf $\alpha=5 \%$. Sehingga hipotesis yang digunakan dalam penelitian ini adalah sebagai berikut.

$\mathrm{H}_{0}$ Diterima jika $\mathrm{H}_{0}$ : nilai $\mathrm{p} \geq \alpha=0,05 \quad$ (tidak signifikan)

$\mathrm{H}_{1}$ Tolak jika $\mathrm{H}_{1}$ : nilai $\mathrm{p}<\alpha=0,05 \quad$ (signifikan)

Keterangan :

$\mathrm{H}_{0}=$ Tidak ada pengaruh motivasi belajar DARING terhadap siswa SDN Pannara Kota Makassar

$\mathrm{H}_{1}=$ Ada pengaruh motivasi belajar DARING terhadap siswa SDN Pannara Kota Makassar. 


\section{BAB IV}

\section{HASIL PENELITIAN DAN PEMBAHASAN}

\section{A. Hasil Penelitian}

SDN Pannara adalah sekolah yang terletak di jalan Antang Raya No. 26 Kecamatan Manggala Kota Makassar. SDN Pannara terdiri atas 388 siswa berdasarkan tingkat pendidikan dari kelas I sampai kelas VI dengan rombongan belajar 12 kelas yang berasal dari masyarakat Kecamatan Manggala dan luar daerah yang dibina oleh 20 tenaga pendidik dan tenaga kependidikan yang berkualifikasi S1.

SDN Pannara merupakan salah satu sekolah yang mendapatkan piagam penghargaan Roemah Robot Goes To School "Solar Energy Robot Assembly" dan banyak mendapat peringkat prestasi akademik maupun non akademik, dalam perlombaan sering memperoleh kejuaraan tingkat kecamatan baik dalam bidang akademik maupun non akademik. Hal ini dapat dilihat dari banyaknya meraih piala dari berbagai macam lomba seperti juara 1 lomba performance, lomba atletik putra dan putri, lomba tari, lomba drama maupun sertifikat-sertifikat yang diperoleh oleh SDN Pannara.

Prestasi dapat diraih karena adanya kerjasama dan kerja keras dari Bapak/Ibu tenaga pendidik dalam membimbing siswa-siswi SDN Pannara Kota Makassar. Disamping itu juga berkat ketekunan, keuletan dan kepatuhan para siswa serta tidak kalah pentingnya peran serta dari orang tua siswa tersebut. Selain berprestasi SDN Pannara juga mengembangkan kebiasaan kepada seluruh siswanya agar selalu santun dalam bertindak dan taqwa kepada Tuhan YME. 
Dalam hal ini para pendidik selalu menanamkan sopan santun dan selalu menghormati orang tua dan gurunya melalui pembiasaan mengucapkan salam setiap masuk ruangan kelas.

\section{Analisis Deskriptif Variabel Penelitian}

a. Gambaran Motivasi Belajar

Pengumpulan data dilakukan dengan menggunakan angket motivasi belajar dan angket minat belajar DARING yang dibagikan kepada 66 siswa kelas VA dan VB SDN Pannara Kota Makassar. Berdasarkan kriteria pengkategorian, maka diperoleh distribusi frekuensi angket motivasi belajar pada tabel berikut:

Tabel 4.1 Statistik Hasil Angket Motivasi Belajar

\begin{tabular}{l|c}
\hline \multicolumn{1}{c|}{ Statistik } & Hasil Angket Motivasi Belajar \\
\hline Ukuran sampel & 66 \\
\hline Mean (rata-rata) & 85.70 \\
\hline Median (nilai tengah) & 86.0000 \\
\hline Mode & 90.00 \\
\hline Std. Deviasi & 4.15829 \\
\hline Varians & 17.291 \\
\hline Rentang & 13.00 \\
\hline Skor terendah & 80.00 \\
\hline Skor tertinggi Jumlah & 93.00 \\
\hline \multicolumn{2}{c}{ Jum } \\
\hline
\end{tabular}

Sumber: Lampiran 20 halaman 101

Berdasarkan tabel diatas menunjukkan bahwa pada hasil angket motivasi belajar yang diberikan kepada 66 siswa SDN Pannara Kota Makassar terdapat 85.70 mean (rata-rata), 86.0000 median (nilai tengah), 90 mode (nilai yang paling sering muncul), 4.15829 standar deviasi, 17.291 varians dan 13.00 rentang. 
Diagram Motivasi Belajar

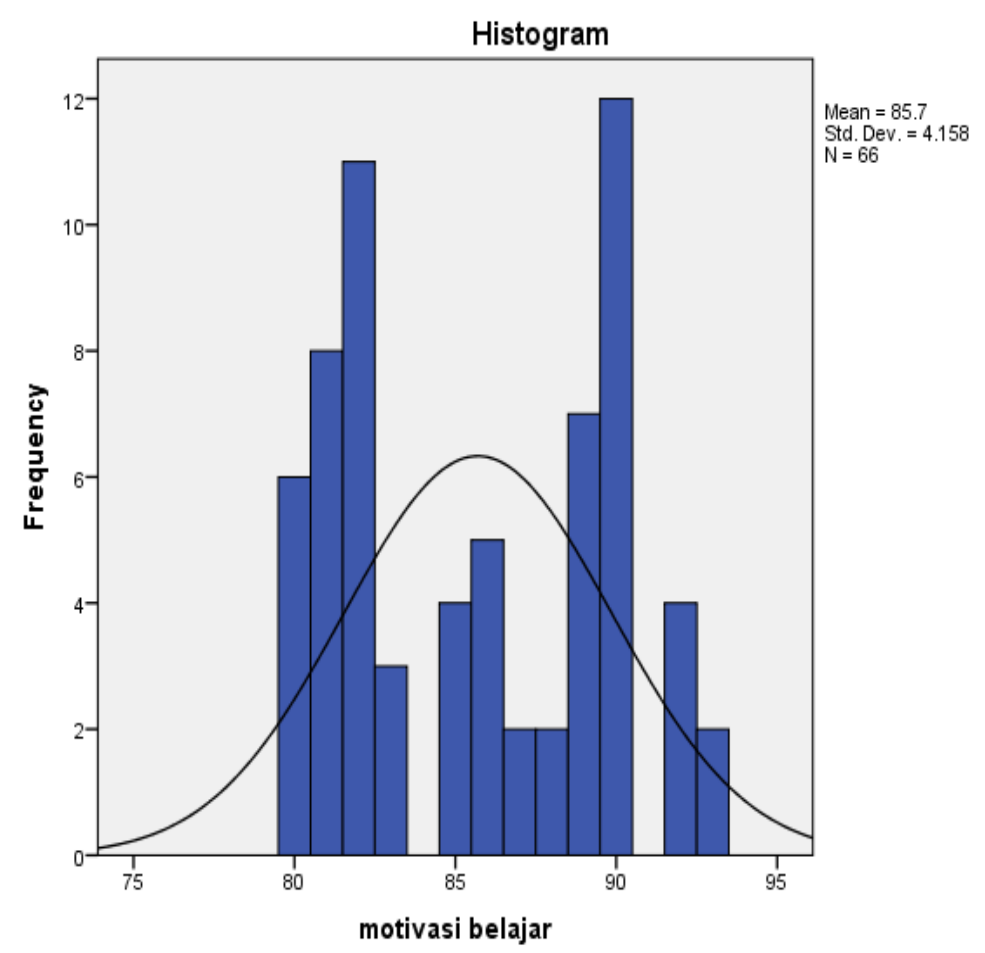

Sumber : Lampiran 22 Halaman 103

Berdasarkan data diatas menunjukkan hasil angket motivasi belajar di SDN Pannara Kota Makassar dengan nilai terendah 80 nilai tertinggi 93 dan nilai rata rata 85.70 sehingga motivasi belajar berada pada kategori sangat berperan

Tabel 4.2 Data Motivasi Belajar SDN Pannara Kota Makassar

\begin{tabular}{lccc}
\hline No. & Interval & Frekuensi & Kategori \\
\hline 1. & $81-100$ & 60 & Sangat Berperan \\
2. & $61-80$ & 6 & Berperan \\
3. & $41-60$ & 0 & Cukup Berperan \\
4. & $21-40$ & 0 & Kurang Berperan \\
5. & $0-20$ & 0 & Tidak Berperan \\
\hline & Jumlah & 66 & \\
\hline
\end{tabular}

Sumber: Lampiran 20 halaman 101 
Berdasarkan pada tabel diatas dapat dikemukakan bahwa pada angket motivasi belajar berada pada kategori sangat berperan. Dari hasil tersebut diketahui bahwa instrumen yang digunakan untuk mengukur angket motivasi belajar ada pada kategori sangat berperan dengan frekuensi 66. Berdasarkan dari tabel dan hasil perhitungan angket motivasi belajar di SDN Pannara Kota Makassar berada pada kategori sangat berperan.

b. Gambaran Motivasi Belajar

Pengumpulan data dilakukan dengan menggunakan angket motivasi belajar yang dibagikan kepada 66 siswa SDN Pannara Kota Makassar. Berdasarkan kriteria pengkategorian, maka diperoleh distribusi frekuensi motivasi belajar pada tabel berikut.

Tabel 4.3 Statistik Hasil Angket Minat Belajar DARING

\begin{tabular}{l|l}
\hline \multicolumn{1}{c|}{ Statistik } & $\begin{array}{c}\text { Hasil Angket Minat Belajar } \\
\text { DARING }\end{array}$ \\
\hline Ukuran sampel & 66 \\
\hline Mean (rata-rata) & 86.05 \\
\hline Median (nilai tengah) & 87.0000 \\
\hline Mode & 81 \\
\hline Std. Deviasi & 4.415 \\
\hline Varians & 19.490 \\
\hline Rentang & 25 \\
\hline Skor terendah & 75 \\
\hline Skor tertinggi Jumlah & 100.00 \\
\hline
\end{tabular}

Sumber: Lampiran 21 halaman 102

Berdasarkan tabel diatas menunjukkan bahwa pada hasil angket minat belajar DARING yang diberikan kepada 66 siswa SDN Pannara Kota Makassar terdapat 86.05 mean (rata-rata), 87.0000 median (nilai tengah), 81 mode (nilai 
yang paling sering muncul), 4.415 standar deviasi, 19.490 varians dan 25 rentang.

Minat Belajar DARING

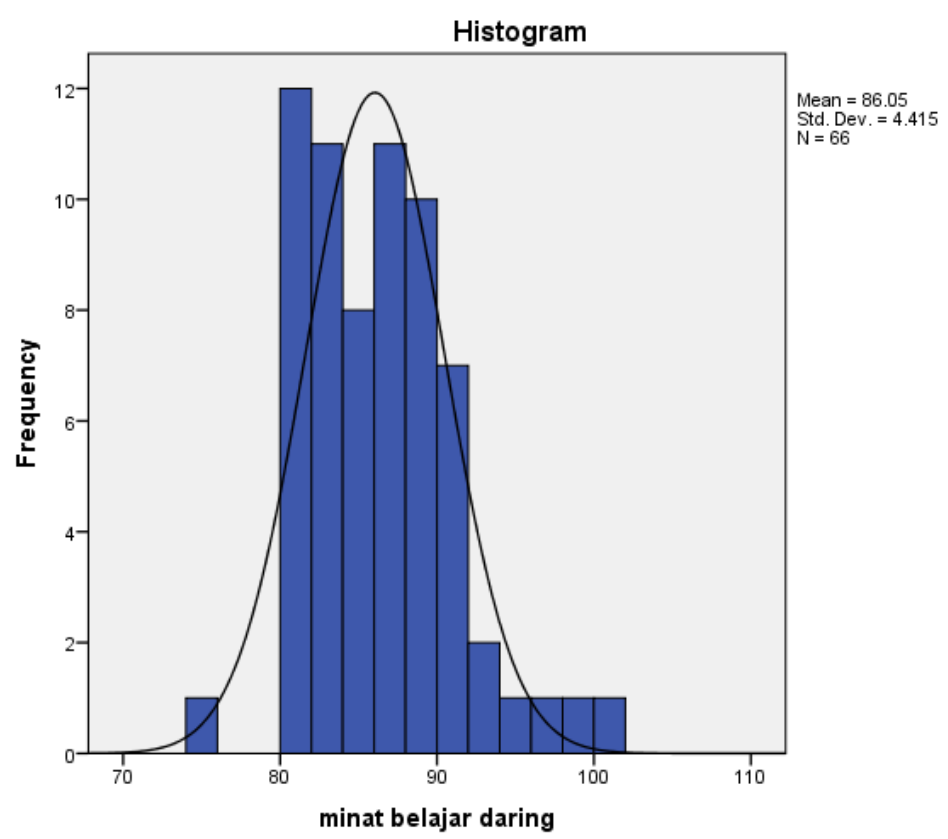

Sumber : Lampiran 22 Halaman 103

Berdasarkan data diatas menunjukkan hasil angket minar belajar DARING siswa SDN Pannara Kota Makassar dengan nilai terendah 75, nilai tertinggi 100.00 dan nilai rata-rata 86.05 , sehingga minat belajar DARING berada pada kategori termotivasi.

Tabel 4.4 Data Minat Belajar DARING Siswa SDN Pannara Kota

\begin{tabular}{lccl} 
& & Makassar & \\
\hline No. & Interval & Frekuensi & \multicolumn{1}{c}{ Kategori } \\
\hline 1. & $81-100$ & 65 & Sangat Termotivasi \\
2. & $61-80$ & 1 & Termotivasi \\
3. & $41-60$ & 0 & Cukup Termotivasi \\
4. & $21-40$ & 0 & Kurang Termotivasi \\
5. & $0-20$ & 0 & Tidak Termotivasi \\
\hline & Jumlah & 66 &
\end{tabular}

Sumber: Lampiran 21 halaman 102 
Berdasarkan data pada tabel diatas dapat dikemukakan bahwa pada angket minat belajar DARING berada pada kategori sangat termotivasi. Dari hasil tersebut diketahui bahwa instrumen yang digunakan untuk mengukur minat belajar DARING ada pada kategori sangat termotivasi dengan frekuensi 66 . Berdasarkan penjelasan dari tabel dan hasil perhitungan angket minat belajar DARING siswa SDN Pannara Kota Makassar berada pada kategori sangat termotivasi.

\section{Analisis Inferensial}

Analisis inferensial yang berupa uji hipotesis dengan menggunakan teknik regresi sederhana dan uji $\mathrm{F}$ dilakukan setelah uji prasyarat analisis yang berupa uji normalitas, uji homogenitas, dan uji linearitas.

a. Uji Prasyarat Analisis

Analisis Prasyarat yang digunakan adalah uji normalitas, uji homogenitas dan uji linearitas.

1) Uji Normalitas

Uji normalitas digunakan untuk mengetahui bahwa data setiap variabel berdistribusi normal atau tidak. data hasil pengujian normalitas terhadap semua variabel di tunjukkan pada table berikut.

Tabel 4.5 Uji Normalitas Motivasi Belajar Dan Minat Belajar DARING

\begin{tabular}{lcc}
\hline Variabel & $\begin{array}{c}\text { Signifikansi } \\
\text { (Unstandardized Residual) }\end{array}$ & Keterangan \\
\hline $\begin{array}{l}\text { Motivasi Belajar } \\
\text { Minat Belajar DARING }\end{array}$ & 0,886 & Berdistribusi \\
\hline
\end{tabular}

Sumber: Lampiran 23 halaman 104 
Berdasarkan hasil analisis data SPSS melalui One Sample Kolmogorov Smirnov Test maka di peroleh nilai signifikansi variabel Motivasi Belajar Dan Minat Belajar DARING sebesar 0,886 dengan merujuk pada kriteria normalitas data bahwa jika nilai signifikansi $>\alpha$ dengan taraf $\alpha=0,05$ maka variabel motivasi belajar dan minat belajar DARING dinyatakan berdistribusi normal. Output dapat dilihat pada lampiran 23 halaman 101

1) Uji Homogenitas

Uji homogenitas digunakan untuk mengetahui data penelitian sama atau homogen. Data hasil pengujian normalitas terhadap semua variabel ditunjukkan pada tabel berikut:

Tabel 4.6 Uji Homogenitas Motivasi Belajar Dan Minat Belajar DARING

\begin{tabular}{lcc}
\hline Variabel & Signifikansi & Keterangan \\
\hline Motivasi Belajar & 0,060 & Homogen \\
Minat Belajar DARING & & \\
\hline \multicolumn{2}{l}{ Sumber: Lampiran 24 halaman 105 }
\end{tabular}

Berdasarkan hasil analisis data SPSS pada kolom Levene's Test For Equality Of Variance maka diperoleh nilai signifikansi variabel motivasi belajar dan minat belajar DARING sebesar 0,060. Dengan merujuk pada kriteria homogenitas data bahwa jika nilai signifikansi $>\alpha$ dengan taraf $\alpha=0,05$ maka variabel motivasi belajar dan minat belajar DARING dinyatakan homogen. Output dapat dilihat pada lampiran 24 halaman 102.

2) Uji Linearitas

Uji linearitas digunakan untuk mengetahui data penelitian memiliki hubungan yang linear antara variabel bebas (motivasi belajar) dengan 
variabel terikat (minat belajar DARING). Uji linearitas pada penelitian ini dapat dilihat tabel berikut.

Tabel 4.7 Uji Linearitas Motivasi Belajar Dan Minat Belajar DARING

\begin{tabular}{lcc}
\hline Variabel & Signifikansi & Keterangan \\
\hline Motivasi Belajar & 0,580 & Linear \\
Minat Belajar Daring & & \\
\hline Sumber: Lampiran 25 Halaman 106
\end{tabular}

Berdasarkan hasil analisis data SPSS pada kolom Deviation From Linearity maka diperoleh nilai signifikansi variabel motivasi belajar dan minat belajar DARING sebesar 0,580. Dengan merujuk pada kriteria linearitas data bahwa jika nilai signifikansi $>\alpha$ dengan taraf $\alpha=0,05$ maka variabel motivasi belajar dan minat belajar DARING dinyatakan linear. Output dapat dilihat pada lampiran 25 halaman 103.

a. Uji Hipotesis

Pengaruh motivasi belajar dan minat belajar DARING siswa SDN Pannara Kota Makassar diperoleh dari hasil olah data yang dilakukan bantuan Sofware SPSS 21 For Windows. Hasil uji regresi terhadap variabel motivasi belajar dan minat belajar DARING terdapat pada tabel berikut:

Tabel. 4.8 Hasil Uji Regresi Pengaruh Motivasi Belajar Terhadap

Minat Belajar DARING

Model Summary

\begin{tabular}{lrrrr}
\hline Model & R & R Square & $\begin{array}{c}\text { Adjusted R } \\
\text { Square }\end{array}$ & $\begin{array}{r}\text { Std. Error of } \\
\text { the Estimate }\end{array}$ \\
\hline 1 & $.349^{\mathrm{a}}$ & .122 & .108 & 4.169 \\
\hline Sumber: Lampiran & 26 halaman & 107 &
\end{tabular}


Berdasarkan tabel diatas pada model summary menunjukkan bahwa nilai $\mathrm{R}$ square 122, hal ini menunjukkan bahwa motivasi belajar berpengaruh terhadap minat belajar DARING.

\begin{tabular}{rlrrrrr}
\hline \multicolumn{2}{c}{ Model } & \multicolumn{7}{c}{ ANOVA } \\
& & Sum of & df & Mean & F & Sig. \\
& Squares & & Square & & \\
\hline \multirow{2}{*}{1} & Regression & 154.646 & 1 & 154.646 & 8.899 & $.000^{\mathrm{b}}$ \\
& Residual & 1112.217 & 64 & 17.378 & & \\
& Total & 1266.864 & 65 & & & \\
\hline
\end{tabular}

Sumber: Lampiran 26 halaman 107

Berdasarkan tabel diatas pada anova menunjukkan bahwa nilai signifikansi lebih kecil dari $\alpha$ hal ini menunjukkan $0,000<0,05$. Hal ini menunjukkan bahwa motivasi belajar berpengaruh terhadap minat belajar DARING.

\section{Coefficients $^{\mathbf{a}}$}

\begin{tabular}{|c|c|c|c|c|c|c|}
\hline \multirow{2}{*}{\multicolumn{2}{|c|}{ Model }} & \multicolumn{2}{|c|}{$\begin{array}{l}\text { Unstandardized } \\
\text { Coefficients }\end{array}$} & \multirow{2}{*}{$\begin{array}{c}\text { Standardized } \\
\text { Coefficients } \\
\text { Beta }\end{array}$} & \multirow[t]{2}{*}{$\mathrm{t}$} & \multirow[t]{2}{*}{ Sig. } \\
\hline & & B & Std. Error & & & \\
\hline \multirow[b]{2}{*}{1} & (Constant) & 54.257 & 10.668 & & 5.086 & .000 \\
\hline & $\begin{array}{l}\text { motivasi } \\
\text { belajar }\end{array}$ & .371 & .124 & .349 & 2.983 & .000 \\
\hline
\end{tabular}

Sumber: Lampiran 26 halaman 107

Berdasarkan hasil yang diperoleh pada tabel diatas dapat dilihat bahwa pengaruh motivasi belajar dengan minat belajar DARING siswa SDN Pannara Kota Makassar dilakukan dengan membandingkan nilai signifikansi (sig) dengan nilai alpha $(\alpha)$. Kriteria pengujian apabila nilai Sig $<\alpha(0,05)$ maka $\mathrm{H}_{0}$ ditolak. Hasil analisis memperoleh nilai Sig 0,000, sesuai dengan kriteria yang ditentukan Sig $(0,000)<(0,05)$ sehingga $\mathrm{H}_{0}$ ditolak dan $\mathrm{H}_{1}$ diterima. Hal ini menunjukkan 
terdapat pengaruh motivasi belajar terhadap minat belajar DARING siswa SDN Pannara Kota Makassar. Output dapat dilihat pada lampiran 26 halaman 104

\section{B. Pembahasan}

Penelitian ini dilakukan di SDN Pannara Kota Makassar bertujuan untuk mengetahui pengaruh motivasi terhadap minat belajar DARING siswa kelas $\mathrm{V}$ SDN Pannara Kota Makassar. Hal yang melatarbelakangi penulis melakukan penelitian ini adalah berdasarkan hasil observasi di SDN Pannara Kota Makassar ditemukan bahwa Minat belajar DARING siswa masih rendah, hal ini ditandai dengan beberapa faktor yang memengaruhi menurunnya minat belajar DARING pada siswa jika ditinjau secara interen dengan situasi belajar selama masa covid19, baik faktor internal maupun faktor eksternal. Berdasarkan data deskriptif yang di peroleh, bahwa faktor eksternal seperti kondisi lingkungan belajar memberikan pengaruh terhadap menurunnya minat belajar siswa. Dengan kondisi belajar yang kondusif dan mendukung, siswa akan lebih semangat dalam belajar sehingga tujuan pembelajaran yang telah di tetapkan dapat tercapai dengan efektif dan efisien

Selama proses pembelajaran DARING mengharuskan siswa untuk belajar dirumahnya masing-masing, guru tidak dapat mendampingi dan mendidik siswa secara langsung sehingga guru tidak dapat melakukan tindakan seperti memberi hadiah, memuji, menegur, menghukum, dan memberikan nasihat. Padahal tindakan-tindakan guru tersebut dapat menguatkan motivasi instrinsik siswa.

Berdasarkan penelitian yang dilakukan di SDN Pannara Kota Makassar, ditemukan bahwa terdapat pengaruh motivasi terhadap minat belajar DARING 
siswa SDN Pannara Kota Makassar. Hal tersebut dapat diketahui setelah pembagian koesioner kepada siswa. Siswa yang menjadi sampel dalam penelitian ini adalah siswa kelas VA dan VB SDN Pannara Kota Makassar yang terdiri dari 66 siswa. Hasil penelitian menggunakan analisis statistik deskriptif dengan nilai rata-rata motivasi belajar adalah 85.70 berada pada kategori sangat berperan dan nilai rata-rata minat belajar DARING adalah 86.05 berada pada kategori sangat termotivasi. Analisis statistik inferensial, hasil uji normalitas motivasi belajar dan minat belajar DARING 0,886 > 0,05 (berdistribusi normal), hasil uji homogenitas adalah $0,60>0,05$ (homogen), hasil uji linearitas adalah 0,580 >0,05 dengan demikian terdapat hubungan yang linear motivasi belajar terhadap minat belajar DARING siswa kelas V. Hasil uji hipotesis menunjukkan nilai Sig 0,000 dengan kriteria Sig $(0,000)<\alpha(0,05)$.

Purwanto R., (2011) menyatakan motivasi di tandai dengan munculnya perasaan dan afeksi seseorang, artinya motivasi relevan dengan persoalanpersoalan kejiwaan, afeksi dan emosi yang dapat menetukan tingkah laku manusia. karena motivasi merupakan respon dari suatu aksi, motivasi akan terangsang dengan adanya tujuan.

Andriani, dkk. (2019) menyatakan minat belajar merupakan sikap ketaatan dalam kegiatan proses belajar, baik yang menyangkut perencanaan jadwal belajar yang di milikinya maupun inisiatif dirinya sendiri melakukan usaha tersebut dengan bersungguh-sungguh dalam belajar. 
Secara hasil temuan penelitian yang menyatakan bahwa motivasi belajar berpengaruh terhadap minat belajar terbukti pada siswa kelas VA dan VB Siswa SDN Pannara Kota Makassar. 


\section{BAB V}

PENUTUP

\section{A. Kesimpulan}

Berdasarkan hasil analisis data baik secara deskriptif maupun inferensial dan pembahasan hasil penelitian maka penulis dapat mengemukakan kesimpulan bahwa gambaran motivasi belajar dan minat belajar DARING siswa di SDN Pannara Kota Makassar tergolong sangat berperan dan sangat termotivasi sehingga terdapat pengaruh motivasi belajar terhadap minat belajar DARING siswa SDN Pannara Kota Makassar.

\section{B. Saran}

Berdasarkan hasil yang dikemukakan diatas maka dapat dikemukakan saran sebagai berikut:

\section{Bagi Guru}

Guru diharapkan dapat memberikan semangat dan memantau serta dapat melakukan kerja sama yang baik dengan orang tua, sehingga tujuan yang ingin dicapai dapat terlaksana meskipun dilaksanakan secara daring

2. Bagi Siswa

Siswa diharapkan memiliki semangat dan mampu mengikuti pembelajaran daring dengan baik agar tetap dapat tercapai hasil yang maksimal.

\section{Bagi Peneliti selanjutnya}

Hasil penelitian ini masih jauh dari kata sempurna, oleh karena itu penulis berharap peneliti selanjutnya dapat mengkaji lebih dalam dari sudut pandang yang berbeda, tidak hanya tentang motivasi belajar dan minat belajar daring 
tetapi dari sudut pandang lain khususnya dalam penggunaan metode ex post facto. 


\section{DAFTAR PUSTAKA}

Abu, A., Jusmawati, J., Makmur, Z., Jumliadi, J., \& Yusuf, M. (2020, July). Problems Faced by IAIN Palu Students in Online Learning in the Middle of the COVID-19 Pandemic. In International Colloquium on Environmental Education(ICEE). Available: https://www. researchgate. net/publication/342601280.

Abustang, P. B. (2018). Pengaruh Lingkungan Sosial Dan Motivasi Terhadap Hasil Belajar Ips Siswa SD Inpres Perumnas Antang Kecamatan Manggala Kota Makassar. PENDAS MAHAKAM: Jurnal Pendidikan Dasar, 3(2), 7684 (diakses pada tanggal 04 Juni 2020, pukul 20:30 WITA)

Andriani, R., \& Rasto, R. (2019). Motivasi Belajar Sebagai determinan hasil belajar siswa. Jurnal Pendidikan Manajemen Perkantoran, 4 (1), 80 https://doi.org/10.17509/jpm.v4iq1.14958

Ahmad, Susanto 2019 Teori Belajar Dan Pembelajaran Disekolah Dasar. Jakarta PT. Prenamedia Group

Ahmadi, Rulam. 2017. Pengantar Pendidikan Asas \& Filsafat Pendidikan. Cetakan 2. Yogyakarta: Ar-Ruzz Media

Fatimah, W., Amaliah, N., \& Abustang, P. B. (2019). Pengaruh Sikap Belajar dan Minat Belajar Terhadap Hail Belajar IPS Siswa di SD Inpres Borong Jambu II Kecamatan Manggala Kota Makassar. SELECTA EDUCATION JURNAL, 1(1). Di akses Kamis 25 Maret 2021

Gustina, F. P. (2020) Pengaruh Kedisiplinan Dan Motivasi Belajar Siswa Saat Pandemi Covid-19 Terhadap Hasil Belajar Ilmu Pengetahuan Alam Pada Siswa Kelas VIII Smp Negeri 2 Getasan Tahun Pelajaran 2019/2020.

Jusmawati., Satriawati., \& R. Irman. (2018). Pengaruh Motivasi Berafiliasi Terhadap Keaktifan Belajar Matematika Siswa SD Inpres Perumnas Antang Kota Makassar. Jurnal Riset Pendidikan Dasar, 01 (2) 158-165 (diakses pada tanggal 01 Mei 2021, pukul 01.00 WITA)

Jusmawati, J., Satriawati, S., \& Sabillah, B. M. (2020). Pengaruh Pembelajaran Berbasis Daring Terhadap Minat Belajar Mahasiswa Pgsd Unimerz Pada Mata Kuliah Pendidikan Matematika. JKPD (Jurnal Kajian Pendidikan Dasar), 5(2), 106-111.

Jamal, Saipul. Peningkatan Hasil Belajar Siswa Menggunakan Model Pembelajaran Peer Teaching Berbasis Masalah Pada Perakitan Komputer Kelas X TKJ di SMK 4 Jeneponto” Skripsi (Fakultas Teknik Unversitas Negeri Makassar, Desember, 2013). 
Muhibbin Syah. 2015. Psikologi Pendidikan. Bandung: Remaja Rosdakarya Aris Yusuf Hamali, S.S., M.M (2018). Pemahaman Manajemen Sumber Daya Manusia Cetakan Ketiga, Diterbitkan Oleh CAPS (Center For Academic Publishing Service

Ninu. S. 2016. Pengaruh Minat Dan Motivasi Bealajar Terhadap Hail Belajar Siswa Kelas V SDN Gugus Werkudoro Kecamatan Tegal Timur Kota Tegal. Skripsi Universitas Negeri Semarang

Oktafia, I, H \& Siti, S.W. (2020 58 ijaran Daring Sebagai Upaya Study Frome Home (SFH). Ju didikan Administrasi Perkantoran https://journal.unesa.ac.id/index.php/jpap

Ricardo,R., \& Meilani, R. I. (2017). Impak Minat dan Motivasi Belajar Terhadap Hasil Belajar Siswa. Jurnal Pendidikan Manajemen Perkantoran, 2(2), 79. https://doi.org/10.17509/jpm.v2i2.8108

Saharutu, M. G. 2020. Pembelajaran Online Minat Belajar Dan Kehidupan SehariHari Mahasiswa Pendidikan Fisika Universitas Sanata Dharma Di Tengah Covid-19. Skripsi FKIP Universitas Sanata Dharma Yogyakarta

Titin Purnamasari. 2017. Pengaruh Motivasi Dan Minat Belajar Terhadap Prestasi Belajar. Skripsi Universitas Negeri Yogyakarta

Winardi. 2016. Kepemimpinan dalam Manajemen. Jakarta: PT. Rineka Cipta Malayu Hasibuan S.P. 2015. Manajemen Sumber Daya Manusia. Jakarta: PT. Bumi Aksara.

Yulmitasari. 2020. Pengaruh Perhatian Orang Tua Terhadap Prestasi Belajar Siswa SD Inpres Borong Jambu II Kota Makassar. Skripsi FKIP Universitas Megarezky

Yaumi, Muhammad. Prinsip-Prinsip Desain Pembelajaran. Kencana Prenada Media Group. Jakarta.2013 